Article

\title{
A Conceptual Framework to Understand the Dynamics of Rural-Urban Linkages for Rural Flood Vulnerability
}

\author{
Ali Jamshed ${ }^{1, *(D)}$, Joern Birkmann ${ }^{1}$, Daniel Feldmeyer ${ }^{1}$ and Irfan Ahmad Rana ${ }^{2}$ D \\ 1 Institute of Spatial and Regional Planning (IREUS), University of Stuttgart, 70569 Stuttgart, Germany; \\ joern.birkmann@ireus.uni-stuttgart.de (J.B.), daniel.feldmeyer@ireus.uni-stuttgart.de (D.F.) \\ 2 Department of Urban and Regional Planning, School of Civil and Environmental Engineering (SCEE) \\ National University of Sciences and Technology (NUST), 44000 Islamabad, Pakistan; \\ irfanrana90@hotmail.com or iarana@nit.nust.edu.pk \\ * Correspondence: ali.jamshed@ireus.uni-stuttgart.de or ali_jam89@hotmail.com; Tel.: +49-711-685-66336
}

Received: 30 November 2019; Accepted: 3 April 2020; Published: 5 April 2020

\begin{abstract}
Rural areas are highly vulnerable to floods due to limited social, economic, and physical resources. Understanding rural vulnerability is vital for developing effective disaster risk reduction strategies. Even though rural areas and cities are intrinsically linked, rural vulnerability was assessed without considering its relation to cities. Numerous theoretical frameworks on systemizing and assessing vulnerability were developed with varying level of scope and depth in terms of scale, dimensions, and components. Nevertheless, these frameworks did not explicitly mention the impact of flood or other hazards on the linkages between spatial units i.e., rural and urban. This study aims to understand and conceptualize the rural vulnerability with respect to the dynamics of rural-urban linkages in the case of flood events. To do so, current literature on rural-urban linkages, vulnerability, as well as factors that influence them were critically reviewed. Taking into account the main elements of rural-urban linkages (flow of people, information, finances, goods and services), components of vulnerability (exposure, susceptibility, and capacity), and factors (social, economic, institutional, infrastructural, spatial, and environmental), a unified framework is proposed. The framework underscores that the role of rural-urban linkages is essential to fully understand rural flood vulnerability. Moreover, the framework highlights the role of spatial factors-city size and proximity to the city-as crucial to comprehend rural vulnerability. This framework can be used as a tool for understanding multifaceted rural vulnerability for climate change adaptation and disaster risk reduction considering spatial development perspective. In this context, empirical investigations can be made to validate the proposed framework and policies can be introduced accordingly. Overall, the proposed framework can help recognize concepts and links of vulnerability, rural-urban dependencies, and rural development dynamics.
\end{abstract}

Keywords: disaster risk; holistic approach; rural-urban relationships; regional development; vulnerability dynamics; rural flooding

\section{Introduction}

Flood events have become more frequent and climate change will further increase the intensity and magnitude of such events [1]. Regions in the world are exposed to different types of floods. In Asia and Africa, impacts of riverine flooding are most devastating, whereas flash flooding played havoc in American continents [2]. Coastal and pluvial flooding and their destructive impacts have become a global issue. Flood impacts resulting from changing climate, along with socioeconomic processes, have significantly revealed the vulnerability of human and ecological 
systems [3]. Vulnerability of these systems does not depend on flood hazards (natural phenomenon) but on location-specific social, economic, demographic, cultural, political, and environmental features $[4,5]$. In this context, vulnerability in Asian, African, and South-American countries is highly associated with economic, physical, and institutional aspects [6-12], while in European and North-American countries, vulnerability is lower due to better infrastructural, governance, and technological setup. Thus, low income and developing regions are more vulnerable to floods due to limited economic and institutional resources to cope and adapt $[13,14]$. Similarly, rural and urban (in this research term "urban area" and "city" are used interchangeably) areas possess varied vulnerability, where the former is deemed more vulnerable $[15,16]$. This can be attributed to the fact that rural areas are characterized by high poverty, greater dependency on agriculture, limited access to services, inadequate physical infrastructure, and limited attention by government authorities [17,18]. These, in turn, characterizes a lesser degree of preparedness and fewer coping mechanisms to weather or climate-related events like floods [19]. In this context, rural vulnerability must be accounted for developing flood risk reduction strategies for larger regions.

Over $90 \%$ of the world's rural population lives in less developed regions [20]. Rural settlements in these regions are usually undersupplied and underdeveloped [21]. Nevertheless, rural areas are undergoing rapid demographic, economic, and governance changes due to rural-urban interdependencies [18]. Rural areas depend on cities, as it provides employment, health, education, emergency services, markets, and information to the rural population. Similarly, cities depend on rural areas for labor, food, and other ecological services [22]. There is a general consensus but limited evidence that these complex dependencies and linkages may be affected due to the impacts of weather or climatic events and can influence the vulnerability of rural households $[18,23]$.

Vulnerability assessment in the face of hazards, disasters, and climate change has emerged as a significant research field and is an integral part of risk assessment [4]. Several theoretical frameworks for vulnerability assessment were developed with different scales (local, national, global), components (exposure, susceptibility/sensitivity, capacity), and dimensions (social, economic, physical, environmental, institutional) depending on the research fields (for example [3,4,24-31]). Multiple studies were conducted to assess rural flood vulnerability incorporating exposure, susceptibility, and capacity components, for example in Romania [32], Ghana [6], South Africa [33], Mozambique [34], Vietnam [8], India [10], Pakistan [11], and Bangladesh [35]. However, none of the frameworks or assessment studies clearly revealed the impact of the rural floods or other rural hazards on the interaction/linkages between spatial units (rural and urban) and its influences on the vulnerability. Although these linkages have been generally discussed in the field of disaster risk reduction and climate change adaptation, they have not been theoretically framed together (see for example [18,23,36-38]).

Spatial and regional development theories have acknowledged linkages between rural and urban areas on the basis of social, economic, and physical development of rural areas (see for example, [39-45]). Srivastava and Shaw [46] emphasized that rural-urban linkages should not only be considered from spatial development perspectives but also how these linkages behave in the case of a flood or other hazard situation. Moreover, several international commitments have called to understand vulnerability from a holistic perspective. Sendai Framework for Disaster Risk Reduction (SFDRR) is a 15 years non-binding agreement with seven targets and four priorities. It aims to reduce disaster risk and losses through shared responsibilities of all stakeholders from the national to local level [47]. Understanding risk in all its dimensions is priority 1 in the SFDRR [47]. Sustainable Development Goals (SDGs) 11 calls for safe and resilient human settlements, and a target of goal 13 calls to strengthen resilience and adaptive capacity to hazards [48]. This requires a comprehensive vulnerability assessment, where urban and rural areas are not only studied in isolation but also how these areas are linked socially, economically, and physically, and must be accounted together for devising strategies for reducing overall vulnerability. In addition, United Nations Human Settlements Programme (UN-Habitat) 'new urban agenda' has also called for integrated initiatives where disaster risk, climate change, and spatial and territorial planning should be harmonized. It has also called for strengthening rural-urban linkages, 
especially in the face of hazards and disasters [49,50]. The Intergovernmental Panel on Climate Change (IPCC) Fifth Assessment Report (AR5) also acknowledged that understanding rural-urban linkages and their management in the face of climate change impacts should be a relevant area of research [18]. Thus, rural vulnerability needs to be filtered from the perspective of rural-urban linkages in the case of a flood or other hazardous event.

Against the aforementioned background, it is imperative to understand rural-urban linkages in the face of hazards and vulnerability. Therefore, this paper aims to develop a unified framework in order to assess how rural-urban linkages modify in a situation of a flood event in rural areas and how it affects the vulnerability of its residents. The proposed framework incorporates theoretical perspective on vulnerability and rural-urban linkages. Moreover, factors that determine variation in vulnerability, as well as linkages, are discussed. Vulnerability is explained in terms of exposure, susceptibility, and capacity to flood events, whereas rural-urban linkages are defined as the flow of people, information, finance, and services. Factors that influence vulnerability and linkages include social, economic, institutional, infrastructural, spatial, and environmental aspects. Collectively, they define rural flood vulnerability. Besides, it ascertains the dynamics of rural-urban linkages in flooding conditions and its role in influencing rural vulnerability. The framework mainly emphases on low income and developing regions and focuses at the local level on flood-prone rural areas.

\section{Theoretical and Conceptual Perspectives on Rural-Urban Linkages and Hazard Vulnerability}

The paper is based on an extensive literature review. A systematic scrutiny of peer-reviewed papers and books on the topic of vulnerability, regional development, and rural-urban linkages was carried out in three phases. In the first phase, conceptual frameworks of vulnerability and its assessment from the perspective of climate change and disasters were shortlisted. In the second phase, theoretical studies on rural-urban linkages, in the context of regional/rural planning and development were searched. Lastly, screening of empirical studies on flood hazard, vulnerability assessment, rural-urban linkages, and rural development was conducted. Five databases including Scopus, ScienceDirect, Web of Science, SpringerLink, and Google Scholar were searched. In addition, multiple authentic sources, for example, published reports, dissertations, and newspaper articles were also examined. Keywords used in three phases of searching the literature include 'flood hazard', 'flood vulnerability', 'vulnerability assessment frameworks', 'regional development theories', 'rural-urban linkages', 'rural-urban interdependencies', 'development disparities', and 'developing countries'. Overall, various combination of these keywords yielded more than six hundred matches. Initially, irrelevant and duplicate publications were excluded based on their titles. Further, the abstracts of the remaining articles were reviewed and prioritized based on the objective of the research. Considering these screening criteria, around one hundred publications were selected for analysis. This literature analysis resulted in linking various aspects of rural-urban linkages, vulnerability, as well as associated factors under the umbrella of flood hazards in order to develop the proposed framework. The following sections provide the definitions, concepts, as well as key elements and components of rural-urban linkages and hazard vulnerability.

\subsection{Rural-Urban Linkages}

The distinction between rural and urban areas is described by many criteria, but there is no general definition available. Rural and urban areas defined based on one or a combination of demographic, economic, infrastructure, and administrative factors [51]. Within these factors, population size and density, the predominant type of economic activity, conformity with legal and administrative status, as well as specific services and facilities are prominent criteria to define rural and urban areas [52]. In many Latin American countries, a population threshold of 2000 or 2500 is used to define urban areas [53]. In South Asian countries—Pakistan, Sri Lanka, Nepal-areas having administrative institutes (municipalities, councils, committees) are declared as urban [52]. Moreover, many African countries define urban with respect to administrative, demographic, and infrastructure characteristics [53].Urban areas can also be referred to a city or a town. In this context, rural areas are considered as inverse of 
urban areas or cities i.e., residual or relative category [54]. Consequently, low population and housing density, high dependence on natural resources for livelihood, limited infrastructure, and social services can characterize rural areas. Although the dichotomy exists between characteristics of rural and urban areas, they are essentially related.

\subsubsection{Theories and Concepts Correspond to Rural-Urban Linkages}

The evolution of relationships or linkages between urban areas/cities and its hinterland resides in spatial and regional development theories. These theories indicate how a city can influence the development of its surrounding rural settlements. Von Thunen's model of agriculture land uses suggested that land rent and transportation cost define the economic activity in the hinterland of a city. Thus, specialization of economic activity in rural areas was based on the distance to the central city [55]. Christaller's central place theory explained the distribution of central places (cities) of different sizes on which their hinterland depend for various services and facilities [56]. It suggests that cities of different sizes can have varied linkages with its rural hinterland, depending upon the type of goods and services as well as spatial proximity to those services. The growth pole model [57] and core-periphery model [58] explained that core areas/cities are the heart of economic activities, whereas periphery/rural areas deliver resources in the form of labor, goods etc. Both theories depicted that core dominates, whereas the periphery is dependent $[57,58]$. This dependence is structured through the relations of exchange between core and periphery. The virtuous cycle model presented how the flow of people, goods, information, and finances between rural and urban areas led to the development of rural areas and their residents [59]. The model includes the spatial dimension by stressing proximity to cities in providing income opportunities and services. The concept of the urban ecological footprint suggests that cities need a larger area than their actual size on which their inhabitants depend for food, natural resources, and absorption of carbon [60,61]. This dependence on food and other natural resources is primarily fulfilled by the rural area and hence demonstrate rural-urban linkages. These theories indicated that rural and urban areas are intrinsically linked. The dominant features in these theories were the size of and proximity to cores/cities for the linkages between rural settlements and cities. However, several other socioeconomic, institutional, infrastructural, spatial, and environmental factors affect these linkages.

\subsubsection{Typologies of Rural-Urban Linkages}

The links between urban and rural areas are identified as of four different types. These are understood as flows of people, information, finances, goods and services [41]. There is a trade-off between rural and urban areas since urban areas depend on rural resources (food, labor, and other) and urban services are vital for rural communities [53]. These linkages are depicted in Figure 1. The flow of people indicates human mobility between rural and urban areas. Human mobility mainly concerns rural areas and is defined as "one response to the uneven spatial dispersal of resources, including natural resources, markets, and employment opportunities" [62]. Mobility takes several forms, for example, temporary, permanent, circular migration, and commuting. The flow of information and ideas represents information exchanges between rural and urban areas regarding population needs, job opportunities, market status, innovations, and new technologies for increased agriculture production, lifestyles, and many other things [21]. Financial flows can be categorized into three types: i) formal, institutional; ii) informal and; iii) investment by government and aid agencies [41]. First, formal flows include micro-credit schemes to economically active poor households from the formal financial institutes such as banks. Second, the informal exchange of finances involves remittance, taking loans from moneylenders, landlords, or relatives. Third is in the form of investments by urban-based government and aid agencies in the human, socioeconomic, and physical development of rural areas [41]. Transaction of goods and services is one of the most important elements of rural-urban linkages. Cities depend on rural resources, for example, agriculture products, water, and others [22]. Rural inhabitants buy durable and non-durable goods for household use as well as to enhance 
production. Agriculture input, tools, building material, and household items are a few examples of goods needed by rural settlements [39]. In terms of services, urban areas provide education, health, and emergency services as well as offer rural households several off-farm opportunities for livelihood diversification [63]. Such flows modify the social, economic, and physical landscape in rural areas. However, these linkages differ from location to location depending on the rural development efforts made to upgrade them. Rural-urban linkages are not autonomous, rather overlap and are closely interlinked since migration flows towards cities are amplified by the increased flow of information to rural settlements on employment prospects that augment the financial flows from cities. For example, off-farm livelihood in cities results in remittances which tends to be used for increasing agriculture production, improving lifestyle, and sending additional household members to urban areas [39,42]. Moreover, better information services on market demand and trends increase the wellbeing of rural entrepreneurs [45]. However, these linkages, if properly understood, are important for framing development policies and are vital in poverty and social vulnerability reduction.

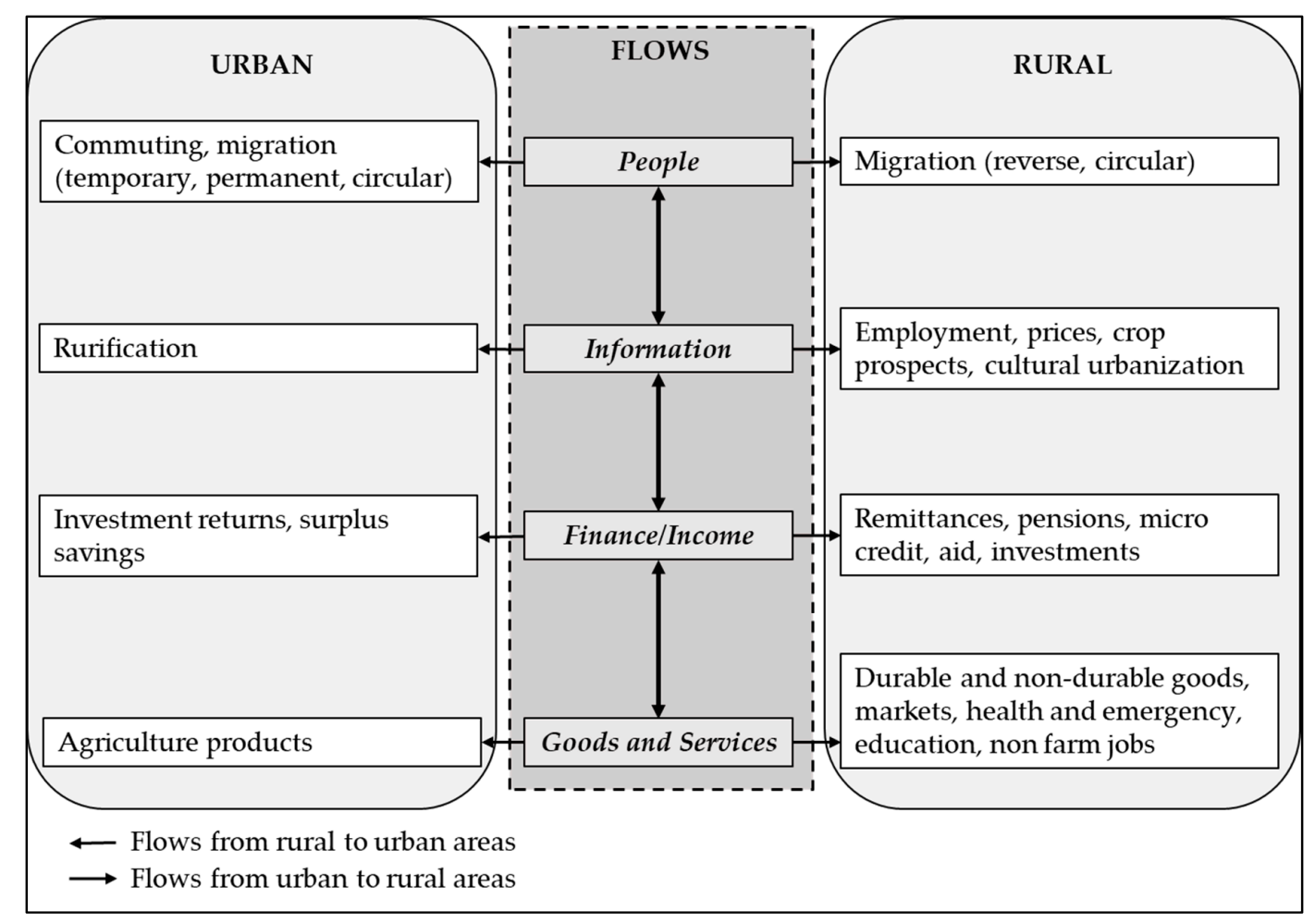

Figure 1. Linkages between rural and urban areas.

\subsection{Vulnerability}

The term vulnerability comes from the Latin word "vulnerare" which means 'to wound'. It indicates the fragility of living and non-living things [64]. The concept has been widely used in the discourse of geographic development and poverty, human ecology, hazard and disaster risk reduction research, as well as climate change adaptation dissertation [65]. Various fields of studies have used the notion according to their applicability, and therefore the conceptual understanding of vulnerability has multiple schools of thought, contexts, dimensions, and professions, which has resulted in numerous definitions and interpretations [65]. Human geography and human ecology have, in particular, theorized vulnerability to environmental change [66]. In the field of disaster risk science, early perspective on vulnerability was in the context of physical resistance of engineering structures. Later, it was viewed as the characteristic of social and environmental processes [36]. Thus, vulnerability has become an important concept in both disaster risk reduction and climate change adaptation research. 


\subsubsection{Definitions}

Various definitions of vulnerability suggest different views on the concept, which may lead to specific priorities in the assessments [65]. A few definitions-both from the perspective of hazard and disaster as well as climate change research-are presented in Table 1. There are several advancements in defining vulnerability with time. Vulnerability was seen as possible losses from a hazard event and mainly focused on individuals. Later, it looked at the socioeconomic characteristic of individual and communities exposed to and affected by hazard or climate change. In the last two decades, the definition of vulnerability has become more system-oriented, not only considering human but also social, economic, physical, and environmental systems and their characteristics. Vulnerability is seen as a function of exposure, susceptibility/sensitivity, and capacity of a system. Moreover, the definitions suggest that the understanding of vulnerability is quite similar, both in hazard and climate change fields. However, IPCC AR5 defined vulnerability in terms of susceptibility and lack of capacities while considering exposure as a separate factor. Nonetheless, the majority consider exposure, susceptibility, and capacity as components of vulnerability (see Figure 2).

Table 1. Development of vulnerability definitions from the context of hazard, disaster risk, environment, and climate change.

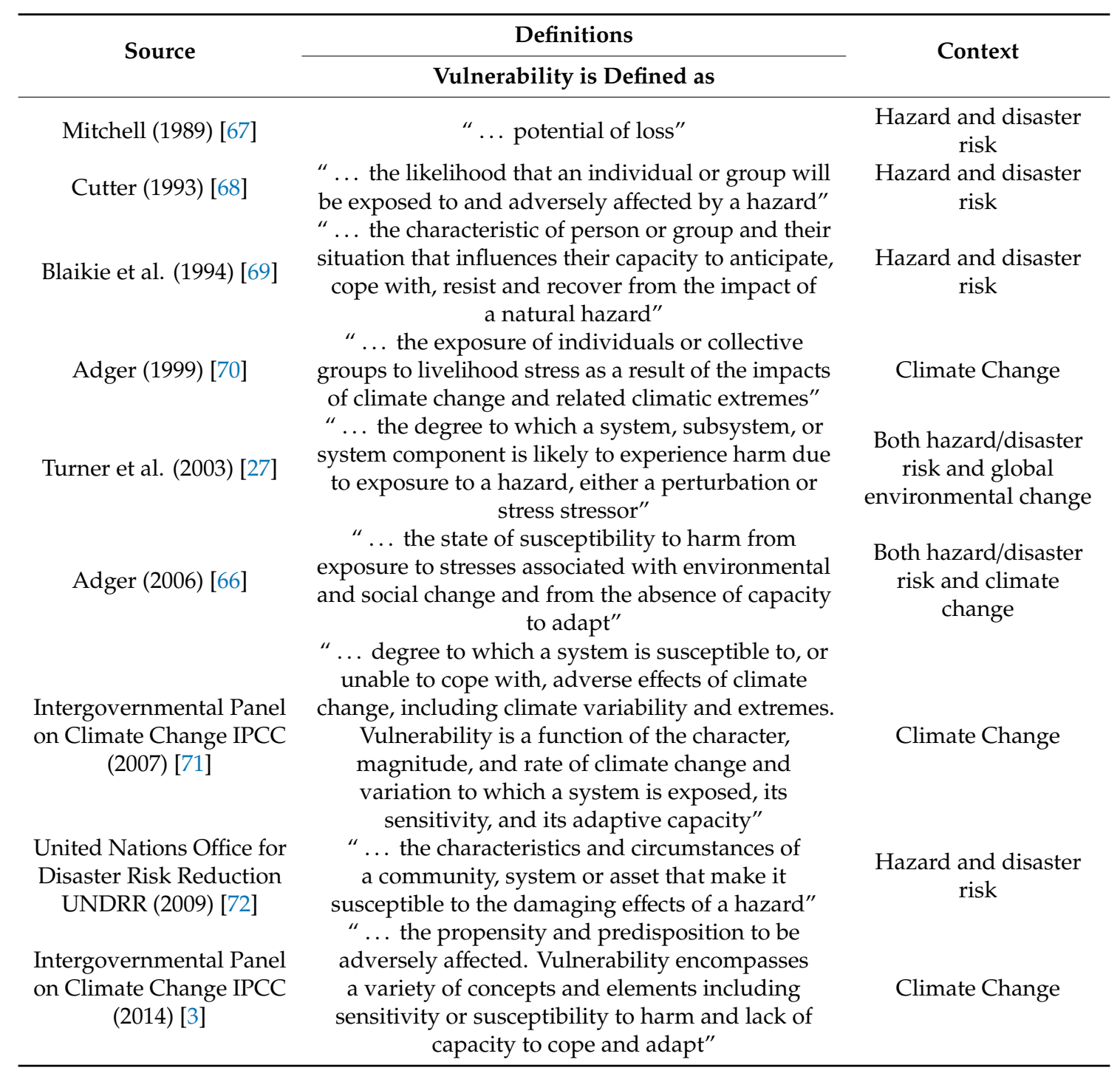




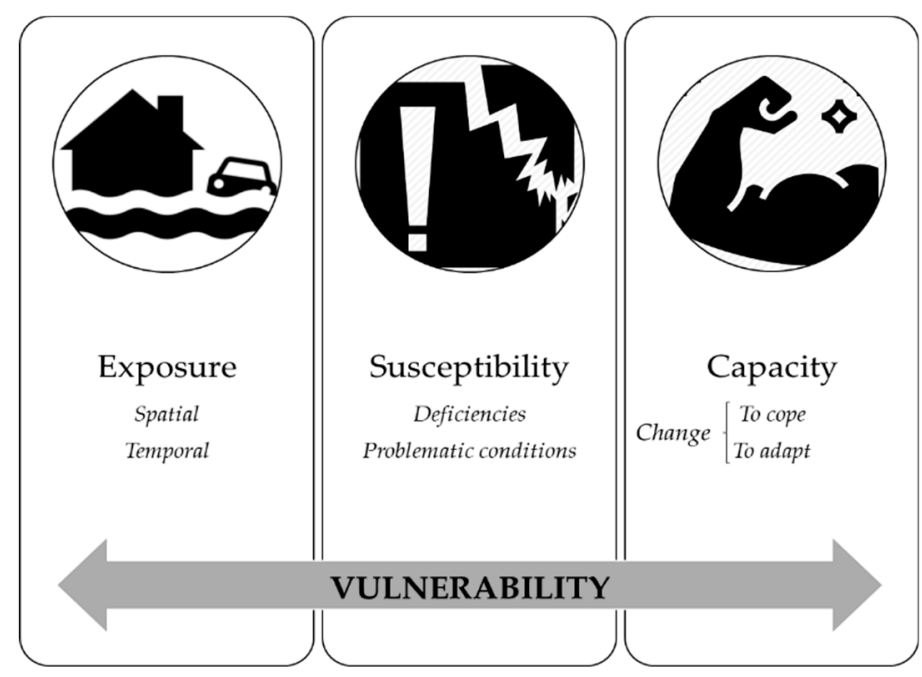

Figure 2. Components of vulnerability.

\subsubsection{Components}

Exposure can be defined as the duration and extent of the system's interaction with the disturbance [66]. Birkmann et al. [4] explained it as "the extent to which a unit of assessment falls within the geographical range of a hazard event". Exposure encompasses physical features of society (infrastructure, buildings), economic systems (livelihoods), as well as human and social systems (people, cultures, values) that are spatially restricted to particular resources and practices that may also be exposed and can be affected by the potential hazard [4]. Degree of exposure can also be explained by losses and damages resulting from a hazard [73]. In addition, exposure is influenced by social systems i.e., processes that lead to danger, for example, social inequalities (exclusion from social networks population), or incapacity to manage the environment and attain assets $[29,74,75]$. Hence, exposure has spatial, temporal, and social aspects.

Susceptibility is one of the central components that explains the degree of vulnerability of exposed elements. Susceptibility - also termed as sensitivity or fragility —is defined, as the degree to which a system is modified or affected by hazard or climate variability [66,76]. It is a predisposition of an element at risk to suffer harm [4]. Susceptibility describes the characteristics and condition of a system which differentiates the magnitude of impacts for a given exposure $[27,31,75]$. These characteristics and conditions mainly refer to social, economic, physical, institutional, and environmental setting of a system [65]. It mainly corresponds to negative characteristics i.e., deficiencies and problematic conditions of a system [73] (see Figure 2). However, a community or system significantly exposed and susceptible to hazard, does not have to be highly vulnerable since capacity influence vulnerability (see Figure 3). 

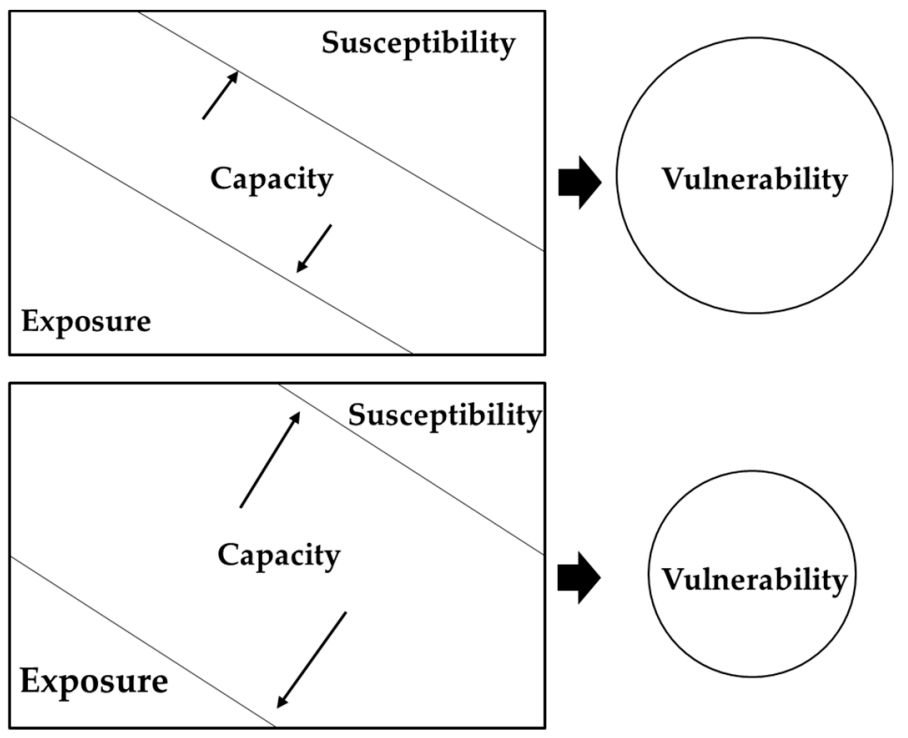

Figure 3. Role of the capacity component in influencing vulnerability [77].

Capacity is defined as "the combination of all the strengths, attributes, and resources available within an organization, community or society to manage and reduce disaster risks and strengthen resilience" [78]. Capacity is broadly categorized in literature as 'coping capacity' and 'adaptive capacity' (see Figure 2). Coping capacity refers to "the ability of people, institutions, organizations, and systems, using available skills, values, beliefs, resources, and opportunities, to address, manage, and overcome adverse conditions in the short to medium term" [76]. It is considered as an ability to respond to a hazardous event and just survive [79]. Coping capacity is considered to be present in a community or system before a hazard [80]. On the other hand, adaptive capacity is the "ability of systems, institutions, humans, and other organisms to adjust to potential damage, to take advantage of opportunities, or to respond to consequences" [76]. It is seen as a more long-term adjustment [79]. Thus, adaptive capacity refers to changing existing practices and behavior considering the past hazardous event. Birkmann et al. [81] indicated that the impact of a hazardous event leads to several formal and informal changes in society. Change is viewed as a response to minimize the current and future impacts and corresponds to capacities to cope and adapt (see Figure 2). It emphasizes that societal changes in response to the impact of an event influence the vulnerability of a system.

\subsubsection{Assessment Frameworks}

Different views and concepts on vulnerability resulted in the formulation of several theoretical models and frameworks [82]. Vulnerability assessment frameworks are used in the development, disaster risk, and climate change adaptation research. These frameworks are crucial in orientation for outlining problems, evolving different methods for measuring and assessing vulnerability as well as help in developing appropriate indicators by focusing on the most relevant factors affecting vulnerability [65]. These frameworks are categorized into three approaches: (a) biophysical, (b) socioeconomic, and (c) integrated assessment $[83,84]$. The biophysical approach considers the impact and associated damages of a hazard event, socioeconomic approach views vulnerability as internal state and structural factors, whereas integrated assessment considers both approaches $[84,85]$. Table 2 provides an evaluation of most commonly used frameworks according to their assessment approach, conceptual understanding of vulnerability, applicability as per spatial scale, and reflection on the interaction between spatial units. Most of the frameworks are based on an integrated assessment approach and consider exposure, susceptibility, and capacity as constituents of vulnerability. Each framework takes into account the different dimensions required for the assessment of vulnerability. Frameworks like 'hazard of 
a place model', 'sustainable livelihood framework', and BBC framework are specific, whereas others are relatively extensive and deal with different spatial levels.

Table 2. Conceptual frameworks with respect to assessment approaches, conceptual understanding of vulnerability, applicability as per spatial scale, and reflection on the interaction between spatial units.

\begin{tabular}{|c|c|c|c|c|c|}
\hline $\begin{array}{l}\text { Name of } \\
\text { Framework }\end{array}$ & $\begin{array}{l}\text { Assessment } \\
\text { Approach }\end{array}$ & $\begin{array}{l}\text { Conceptualization of } \\
\text { Vulnerability }\end{array}$ & $\begin{array}{l}\text { Vulnerability } \\
\text { Dimensions }\end{array}$ & $\begin{array}{l}\text { Spatial } \\
\text { Scale }\end{array}$ & $\begin{array}{c}\text { Interaction } \\
\text { between } \\
\text { Spatial Units } \\
\text { i.e., Rural and } \\
\text { Urban }\end{array}$ \\
\hline $\begin{array}{l}\text { Hazard of place } \\
\text { model [24] }\end{array}$ & Integrated & $\begin{array}{c}\text { Combination of } \\
\text { biophysical and social } \\
\text { vulnerability }\end{array}$ & $\begin{array}{c}\text { Social, } \\
\text { Geographical }\end{array}$ & Local/place & No \\
\hline $\begin{array}{c}\text { Sustainable } \\
\text { livelihood } \\
\text { framework } \\
\text { [25] }\end{array}$ & Socioeconomic & $\begin{array}{l}\text { Shocks, trends, and } \\
\text { seasonality which can be } \\
\text { influenced by } \\
\text { transforming structures }\end{array}$ & $\begin{array}{l}\text { Human, Social, } \\
\text { Financial, } \\
\text { Physical, } \\
\text { Natural }\end{array}$ & Local/place & No \\
\hline $\begin{array}{c}\text { Holistic } \\
\text { approach [26] }\end{array}$ & Integrated & $\begin{array}{l}\text { Function of exposure, } \\
\text { susceptibility/fragility, } \\
\text { and ability to } \\
\text { cope/recover }\end{array}$ & $\begin{array}{c}\text { Social, } \\
\text { Economic, } \\
\text { Physical }\end{array}$ & $\begin{array}{l}\text { Local to } \\
\text { national }\end{array}$ & No \\
\hline $\begin{array}{l}\text { Vulnerability in } \\
\text { the context of } \\
\text { socio-ecological } \\
\text { perspective [27] }\end{array}$ & Integrated & $\begin{array}{l}\text { Function of exposure, } \\
\text { sensitivity, and resilience }\end{array}$ & $\begin{array}{c}\text { Coupled } \\
\text { human and } \\
\text { environment }\end{array}$ & $\begin{array}{l}\text { Local to } \\
\text { global }\end{array}$ & No \\
\hline $\begin{array}{c}\text { The pressure } \\
\text { and release } \\
\text { (PAR) model } \\
{[28]}\end{array}$ & Socioeconomic & $\begin{array}{l}\text { Explained by three } \\
\text { progressive level: root } \\
\text { causes } \\
\text { dynamic pressure and } \\
\text { unsafe conditions }\end{array}$ & $\begin{array}{c}\text { Physical } \\
\text { environment, } \\
\text { Local } \\
\text { Economic, } \\
\text { Social relation, } \\
\text { Public action } \\
\text { and institutions } \\
1\end{array}$ & $\begin{array}{l}\text { Local to } \\
\text { global }\end{array}$ & No \\
\hline $\begin{array}{c}\text { BBC } \\
\text { framework [30] }\end{array}$ & Integrated & $\begin{array}{l}\text { Function of exposure, } \\
\text { susceptibility, and } \\
\text { coping capacity }\end{array}$ & $\begin{array}{c}\text { Social, } \\
\text { Economic, } \\
\text { Environmental }\end{array}$ & Local/place & No \\
\hline $\begin{array}{l}\text { Second } \\
\text { generation } \\
\text { vulnerability } \\
\text { assessment } \\
\text { framework [31] }\end{array}$ & Integrated & $\begin{array}{c}\text { Function of exposure, } \\
\text { sensitivity and adaptive } \\
\text { capacity }\end{array}$ & Not specified & $\begin{array}{l}\text { Local to } \\
\text { global }\end{array}$ & No \\
\hline $\begin{array}{l}\text { Methods for } \\
\text { the Improvement } \\
\text { of Vulnerability } \\
\text { Assessment in } \\
\text { Europe } \\
\text { (MOVE) } \\
\text { framework [4] }\end{array}$ & Integrated & $\begin{array}{l}\text { Function of exposure, } \\
\text { susceptibility, and } \\
\text { resilience }\end{array}$ & $\begin{array}{l}\text { Physical, } \\
\text { Ecological, } \\
\text { Social } \\
\text { Economic, } \\
\text { Cultural } \\
\text { Intuitional }\end{array}$ & $\begin{array}{l}\text { Local to } \\
\text { global }\end{array}$ & No \\
\hline $\begin{array}{l}\text { Intergovernmental } \\
\text { Panel on } \\
\text { Climate } \\
\text { Change } \\
\text { vulnerability } \\
\text { and risk } \\
\text { framework [3] }\end{array}$ & Socioeconomic & $\begin{array}{c}\text { Consist of susceptibility } \\
\text { and capacity to cope and } \\
\text { adapt }\end{array}$ & $\begin{array}{l}\text { Environment, } \\
\text { Social, } \\
\text { Economic }^{2}\end{array}$ & $\begin{array}{l}\text { Local to } \\
\text { global }\end{array}$ & No \\
\hline
\end{tabular}

${ }^{1}$ As specified in the section that deals with “Unsafe Conditions". ${ }^{2}$ As specified in IPCC SREX Report 2012.

The hazard of place model considers the geographical features in addition to others to assess the vulnerability of places [24]. Turner et al. [27] identified human and environmental conditions at the center of vulnerability. They explained components of exposure and various responses to hazards to assess vulnerability. Füssel et al. [31] maintained that climate change impacts can be explained 
by exposure and susceptibility to climatic and non-climatic factor. Vulnerability is the outcome because of the interplay of exposure, sensitivity, and adaptive capacity. Birkmann et al. [4] defined the multiple dimension (physical, ecological, social, economic, cultural, and institutional) based on which vulnerability of communities differ. In addition, exposure is defined in both spatial and temporal terms. All the frameworks refer to the characteristic of a particular community, spatial unit, or system at a place, which is exposed to a natural hazard or climate change. These frameworks also draw attention to the several elements and linkages (i.e., human and environmental factors) that potentially affect the vulnerability. However, these frameworks underestimate the role of interaction and linkages between two systems that can influence the exposure, susceptibility, and capacity of one, which is hazard prone. For example, how a city influences the vulnerability of surrounding flood-prone rural settlements since there are several demographic, social, economic, information, infrastructural linkages between them as defined in Section 2.1. Thus, this study fills this gap by proposing a framework exclusively for rural-urban linkages.

\section{Flood Hazards, Rural-Urban Linkages, and Rural Vulnerability}

In developing countries, the rural population depend on cities especially in the post-flood situation hence, making the rural link with the city a crucial aspect in case of a hazard or disaster situation. This section delivers information on how various linkages between rural and urban areas can be affected due to the occurrence of rural flooding and can influence the vulnerability of households. In addition, this section gives detail on multiple factors that drive linkages and flood vulnerability.

\subsection{Rural-Urban Linkages under the Umbrella of Floods Events}

\subsubsection{People}

Flood event in rural areas affect the flow of people and can result in various mobility patterns during and post-flood situation such as commuting, evacuation, displacement, and migration [86-88]. These movements in flood-prone rural areas are mainly towards urban areas. Evacuation and displacement are mostly in the direction of towns and cities since relief activities and camps are concentrated in and around those areas, for example, in Bangladesh [89], Pakistan [90], and India [91]. People also migrate for short and long term to cities in the aftermath of a flood event for employment [92]. Apart from displacement, all these movements are increasingly seen as a coping and adaptation response to floods $[38,93,94]$. Contrarily, short and long term migration also offers challenges in the form of expensive living in cities, getting reasonable jobs, good accommodation, and weaken social cohesion which may aggravate vulnerability $[95,96]$. Thus, an actual or potential flood event can modify mobility patterns of rural communities, which as a result, affect the vulnerability of rural communities.

\subsubsection{Information}

The flow of information can be instrumental in shaping vulnerability patterns of rural households. In the case of flood, information on flood warnings is disseminated from cities that can help rural households prepare for the event. The resulting evacuation alters the exposure of people and their assets [34]. Information delivery on getting financial aid, building shelter, food distribution, preventing diseases, and other post-flood welfare activities come from cities [21,97]. Moreover, frequent access to information following an event on the weather forecast, new seeds and fertilizers, as well as improved agricultural practices, help rural farmers to change the cropping pattern and adapt accordingly [98]. In short, the flow of information from cities can help a rural household to reduce their exposure, susceptibilities, and increase capacities against the pre, during, and post-flood situation.

\subsubsection{Finance}

Financial flows from cities to rural areas are an important aspect that influences vulnerability to floods. In most of the cases, extreme events and disasters generate resource inflows to affected areas [81], 
particularly in the form of finance. Distribution of financial aid is common to compensate for flood losses by government and donor agencies [82]. Remittance from rural migrants in cities is important in sustaining rural households' livelihoods and becomes imperative during and after a hazardous event to cope and adapt $[99,100]$. Moreover, increased credit demand from rural farmers following a flood can change financial flows. Hence, the occurrence of a flood event stimulates the financial flows from cities for the redevelopment of rural infrastructure and aids households to recover from a flood event.

\subsubsection{Goods and Services}

Cities provide various services and goods to rural areas that help them cope, recover, and adapt in case of a flood event. Cities deliver emergency services for evacuation and relief in case of occurrence of a flood event and provide avenues to diversify their income [36,38]. Moreover, cities provide various services like health, credits, agriculture extension, livelihood, and farm management training that help rural households during and after a flood event [101,102]. In the aftermath of a flood, a city provides durable and non-durable goods through markets and aid agencies, for example, material for shelter and house construction, fertilizers, tools and technology, and food items that help rural households to cope and revive their livelihoods $[103,104]$. On the contrary, flood impacts can restrict access to goods and services and hence change dependence on cities. Therefore, the flow of goods and services from cities to rural areas affects vulnerability to flooding both in the short and long term. Moreover, the impacts of flooding on rural agricultural production indirectly affect the urban population due to food shortage or its inflation and can influence urban vulnerability.

Overall, linkages between rural and urban areas influence the vulnerability in the case of flood events. These flows behave differently than normal in the case of a flood by changing mobility patterns, intensifying flow of goods, information, and finances. However, various factors are involved that drive variation, both in linkages and flood vulnerability.

\subsection{Driving Factors of Rural-Urban Linkages and Flood Vulnerability}

Factors that drive variation in both rural-urban linkages and flood vulnerability are quite similar. In both fields, these are broadly divided into social, economic, infrastructural, institutional, spatial, and environmental factors $[39,65]$. Figure 4 demonstrates the driving factors of rural linkages with cities and vulnerability to flood events.

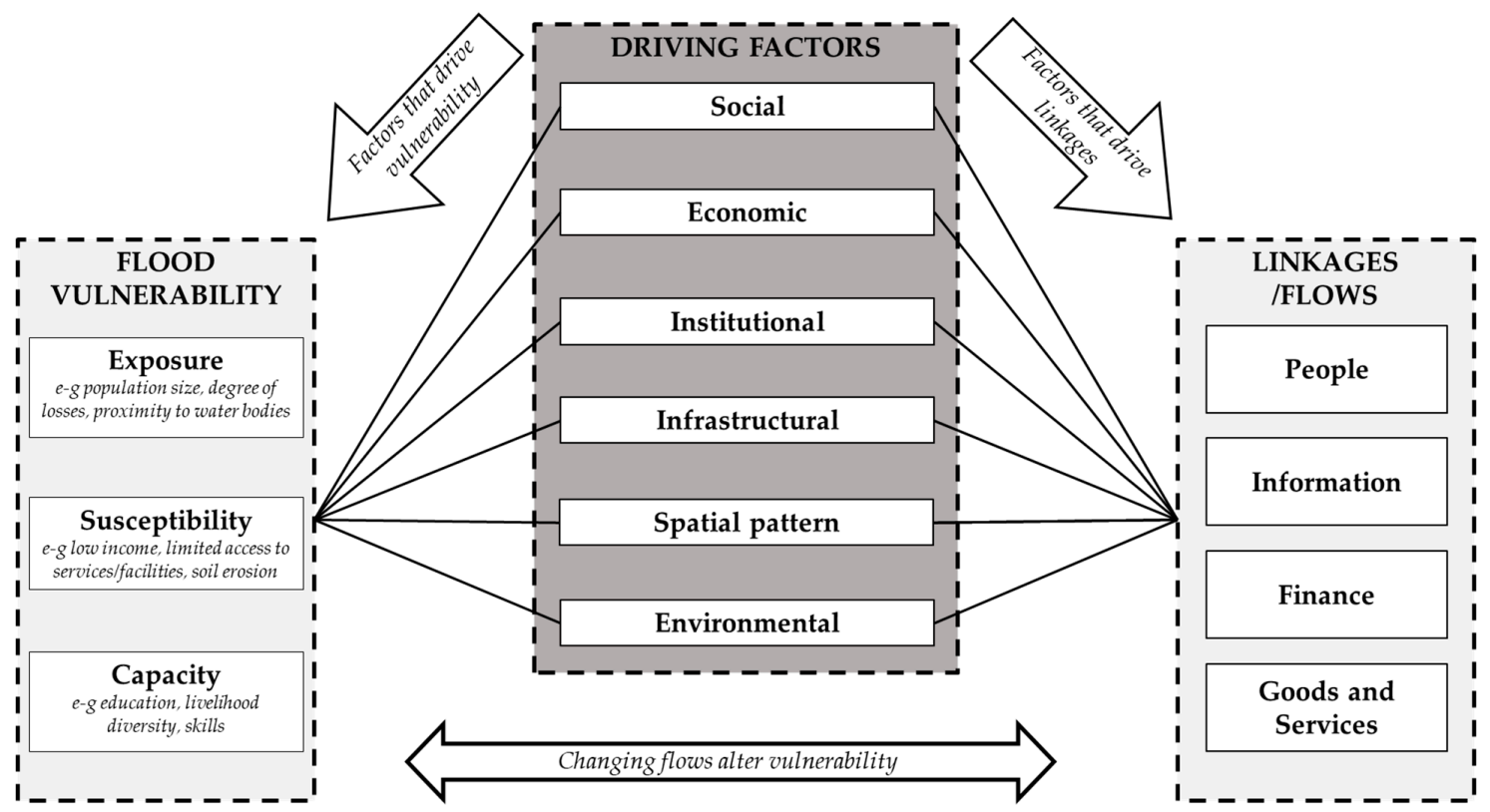

Figure 4. Interconnections of driving factors, rural-urban linkages, and flood vulnerability. 


\subsubsection{Social}

Social factors represent demography, health, education, possession of skills, and social network. Demographic aspects such as age, gender, health, and education likely to affect the access to material assets such as tools, technology, and understanding of the different market process $[40,84]$. These demographic aspects also affect mobility patterns [62]. Possession of different skills helps increase crop production, but rural wellbeing depends on urban areas for the transfer of these skills by involving nonfarm activities [42]. Social networks are vital in terms of getting market and technology information [105], migration to cities [106,107], and getting access to credits [108]. In the context of flood vulnerability, population size reflects exposure to flood [109]. Lianxiao et al. [110] highlighted that the elderly and children are more susceptible to flood due to decreased strength [110]. Females are considered susceptible due to limited social networks as well as restricted access to information and other resources which are resulted from traditional and cultural norms [8,111]. Health status of household members, for example, physical and mental issues, also influence susceptibility as it restricts mobility and requires special attention in the case of the flood event [109,112]. Education level indicates capacity as educated people are well informed on flood issues and better understand flood warning systems [11,113]. Households with skills can better cope with the floods using their skills to diversify their livelihoods in Pakistan [9,82]. Scheuer et al. [114] and Boon [115] maintained that social networks are useful in the case of a hazard event to get information on warnings, help to move belongings and people to safety, as well as accessing relief and aid items $[114,115]$. Hence, social factors influence exposure, susceptibility, and capacity as well as flows between rural and urban areas (see Figure 4).

\subsubsection{Economic}

Economic factors represent income level, occupational structures, number of earning members, access to land and resources, and type of production in agriculture [39,40]. Income level affects the demand for urban goods and hence alters the interaction between rural and urban settlements [42,59]. The sector of occupation and type of production in which rural households are employed indicates how it is interacting with cities. For example, if a rural household is involved in dairy farming, then it can have more intense linkages with the city in terms of mobility to sell dairy products, getting price information, as well as buying tools, inputs, and medicines for animals. Inequality in income and resources can modify mobility patterns where people migrate seasonally or permanently to cities in order to increase their income [42]. In flood vulnerability discourse, households with a low-income level have limited financial ability to cope and adapt [112,116]. Further, such households find difficulty in buying basic necessities during and after the flood due to price inflation in Pakistan [103]. The susceptibility of household or community also depends on the occupation in which they are employed. Farm wage laborers working in flood-prone areas are more susceptible, followed by farmers [9]. Jamshed et al. [82] highlighted that a flood event can destroy crops and other exposed financial assets and economically affect such people [82]. However, occupational diversity leading to multiple income sources increases capacity $[117,118]$. Bhattacharjee et al. [10] maintained that vulnerability is also altered by the economic dependency ratio, where a higher number of earning members expand the capacity of the household. Thus, economic factors drive flows and vulnerability as depicted in Figure 4.

\subsubsection{Institutional}

Institutional factors refer to governance and institutional structure [40]. Institutions are mainly based in cities and regulate flows between rural areas and cities. The presence of local administrative departments, credit institutions, market cooperatives, and private organizations in cities significantly alters the social, economic, and physical development of surrounding rural settlements [63]. Institutional and governance factors are vital in determining flood vulnerability [70]. Laws and regulations as 
well as its enforcement by relevant institutes restrict development in flood-prone areas and reduce exposure. Rana et al. [9] found that timely dissemination of flood warnings from responsible institutes also limits exposure of the population and their moveable assets to floods in Pakistan [9]. In case of a flood event, both formal and informal institutions manage emergency and recovery by carrying out evacuation operations, provide relief items, and give compensation in form of financial aid, building materials, seeds, fertilizers, as well as reconstruct rural infrastructure in Brazil, India, and Bangladesh [82,119-121]. Moreover, these institutions provide training on skill development for livelihood diversification, disaster awareness programs, extension services on changing cropping patterns, information of weather and new technologies in the aftermath of flood hazards $[98,104]$. Credit institutions provide loans and allow remittance flows during and after a flood event for a revival of livelihoods. All these aspects reduce exposure and susceptibility and increase capacity. However, all these activities depend on the type of institutions and their abilities that drive linkages and the level of vulnerability.

\subsubsection{Infrastructural}

Infrastructure factors correspond to the state of the built environment and represent community infrastructure facilities which are extremely imperative for various flows $[39,122]$. These infrastructure facilities are transport systems, telecommunication and electricity coverage, markets and production systems, health, and education. Availability and quality of these services have a significant influence on the flow of people, finances, information and goods [21,41,123-125]. Infrastructural factors are vital in influencing vulnerability to flooding hazards. Limited access as well as damages resulting from floods to farm-market roads, sanitation facilities, water supply, telecommunication, and electricity services, increase vulnerability $[73,101]$. In South Asian and African countries, poor and/or damaged infrastructure restricts the mobility of rural households, increases transportation cost, hinders rescue and relief operations, affects the information exchange between cities and rural areas in the case of the flood event $[5,40,82]$. Damages to the basic village health centers and education facilities also increase the susceptibility of rural households in Bangladesh [119]. Distance to emergency facilities, health centers, and metaled roads are important physical features that influence the susceptibility to flood in Sudan [126], Pakistan [127], and India [120]. Hence, availability and quality of infrastructure modify both flows and vulnerability.

\subsubsection{Spatial Pattern}

Linkages differ depending upon the spatial pattern of settlements i.e., how the settlements are distributed over space [39]. The size of the city and rural settlement's proximity to the city is important in this regard $[19,44,59,128,129]$. The size of the city is not only determined by the population but also by its functional and economic variety [19]. Hsu [130] and Romic [131] argued that functional and economic diversity increases with the size of the city. City size influences the level and extent of services and facilities provided to hinterlands and determines the socioeconomic and physical development of rural areas [51,132]. Employment growth [133] and poverty rates [44,134] in rural areas are influenced by the size of their neighboring cities. Rural settlement physical proximity (in terms of distance) to town or city is key in rural livelihood development and also affects the various flows $[39,129,135]$. Distance to cities can alter mobility and information patterns as well as education, skill, and income level of rural communities $[39,136,137]$. Rural households in close proximity to cities are economically well-off due to diversified livelihoods $[128,137,138]$. Quality and access to infrastructure and communication facilities in rural areas are modified by distance to cities in India and Ethiopia [129,137]. Moreover, distance to urban markets and metaled roads influence the livelihood security of rural households [139]. Studies on the vulnerability of city sizes suggested that larger cities are less vulnerable to hazards compared to small cities as they have more social, economic, physical, and institutional resources to deal with hazards [15,140-142]. In terms of rural households' distance to cities, Maddison [143] argued that farmers living in close proximity to markets are more able to adapt 
to climate change in eleven African countries. Abid et al. [127] found the same in Pakistan. Pandey et al. [144] underscored that rural households living far more district headquarter were more vulnerable to climate change in India. In short, availability, quality, and accessibility of infrastructure facilities affect the exposure, susceptibility, and capacity. Nonetheless, flood vulnerability of rural settlements in relation to the spatial factors like the size of the city and proximity has widely been neglected.

\subsubsection{Environment}

The environment aspects-which, for example, include the presence of river bodies, soil quality, degree of erosion, water availability, or other ecosystem services-are important factors that affect the rural linkages with an urban area. A high degree of erosion, unavailability of water, and bad soil quality can force people to seasonally or permanently migrate [40]. The occurrence of flood affects natural factors such as soil and water quality which influence the type of functions supported by rural areas [39]. A flood can degrade the farmland and affect crop cultivation and productivity, whereas the degradation of water quality affects human and crop health $[82,113,145]$. Reduced crop productivity lowers the income of rural households engaged in farming and has ramifications for food availability in an urban area [21]. Moreover, proximity to the source of the flooding, for example, river bodies, increases exposure [146,147]. Thus, the state of environmental factors affects linkages and vulnerability to floods.

These above-mentioned factors determine the intensity of linkages and variability in vulnerability and affect the well-being of rural communities. These factors are mutually dependent, for example, size of and proximity to a city highlights the level and quality of infrastructure facilities in its rural hinterland. Moreover, city size and distance not only are important in terms of infrastructure but are also vital in modifying the socioeconomic features of surrounding rural communities. Additionally, flood vulnerability and linkages are related and changing linkages due to a flood event can alter the vulnerability of rural households.

\section{The Conceptual Framework}

Against the backdrop of discussion in the previous sections, a conceptual framework is proposed by integrating concepts of rural-urban linkages (backed by the work of Tacoli [53] and Douglass [39]) and flood vulnerability (supported by the theoretical contributions of Cutter [24], Turner et al. [27], Füssel and Klein [31], and Birkmann et al. [4]), which is the main contribution of this paper (see Section 2.2.3 for details). Figure 5 demonstrates the conceptual framework. The proposed framework indicates how rural linkages with its neighboring city influence with the occurrence of a flood event and how in turn it shapes the vulnerability of rural households. The proposed framework consists of three segments: (1) rural-urban linkages, (2) flood vulnerability, and (3) factors that affect linkages and vulnerability.

1. Rural-urban linkages discourse considers rural areas, not as isolated entities but also characterized by their relationship with their nearest urban areas. This relationship is represented by the flow of people, information, finances, goods, and services, which bind both areas and helps in development, particularly of rural households and communities.

2. Flood is defined as a potential event caused by a natural or anthropogenic phenomenon that brings a huge amount of water out of its natural or artificial precincts onto land that is generally dry, and impacts the exposed elements of communities in a rural setting over a period of time. A flood event can have social, economic, physical, and environmental impacts, which can be both direct and indirect. Vulnerability is considered through the integrated approach, which recognizes vulnerability as having three components i.e., exposure, susceptibility, and capacity which can be influenced depending on linkages. Exposure indicates social, economic, and physical features of a rural community that are spatially and temporally fall within the geographical range of the flood, whereas the degree of exposure is explained by the extent to which these features experience 
losses and damages. Susceptibility is defined as conditions of exposed social, economic, and physical systems that make rural communities experience harm. Capacity is the ability of rural communities to address, manage, overcome, and adjust to flood. It includes both short and long-term measures that help rural communities overcome adverse conditions and potential damages. Exposure and susceptibility are seen as negative, whereas capacity as the positive side of vulnerability.

3. Factors that drive or influence rural-urban linkages and vulnerability include social (demography, health, education, possession of skills, and social network), economic (income, occupation, resources, livelihood diversity), institutional (local administration, public and private credit institutes, development organizations), infrastructural (roads, electricity, transport, telecommunications, markets, schools, and health), spatial (city size and proximity), environmental (water bodies, soil and water quality, erosion, flood proneness).

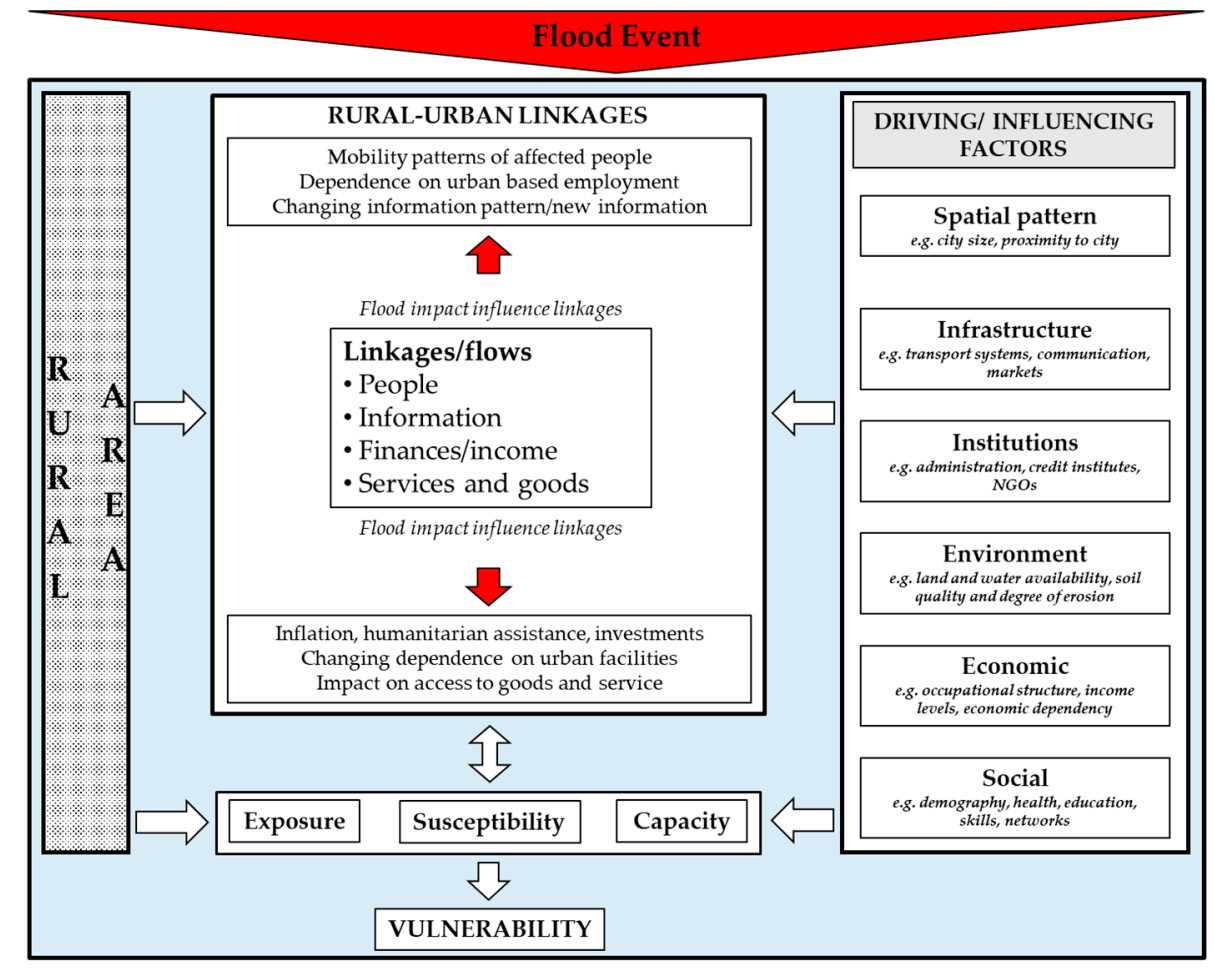

Figure 5. A conceptual framework to understand the dynamics of rural-urban linkages and its influence on rural flood vulnerability.

Rural communities, linkages, and factors are under the umbrella of the flood event in order to display rural area as prone to flooding. As shown in Figure 5, rural-urban linkages and components of vulnerability (exposure, susceptibility, and capacity) are influenced by multiple factors. These factors shape the internal characteristics of rural communities and direct behavior and intensity of linkages as presented in Section 3.2. The flow of people, information, finances, goods and services also customize exposure, susceptibility, and capacity of rural households. In the case of a flood event, cities provide information, multiple services, goods, and finances to rural areas; for example, flood warning, evacuation and relief services, non-food items etc. (see Section 3.1). These flows can alter exposure, susceptibility, and capacity of rural households.

Following the idea that impact can lead to societal changes [81], it is argued that the impact (both direct and indirect) of a flood event can modify certain linkages which affect exposure, susceptibility, and capacity. These changes can reflect the variation in the mobility pattern for income diversification, more frequent access to (new) information on building construction, farming techniques, technology, 
more financial flows in the form of aids, remittances, credit for the household recovery, and investment for the overall development of rural areas. In Sri Lanka and Indonesia, disaster awareness and preparedness training, microfinance, aid distribution and provision of goods for livelihood revival (boats and fishing equipment) were main responses to the Indian Ocean Tsunami [81]. On the other hand, long-term displacement, destruction of infrastructure leading to high transportation cost and inflation can restrict different flows. In Nigeria, heavy rain badly affected feeder roads and restricted the access of farmers to city markets due to high transport cost and led to the loss of income [40]. In Pakistan, floods interrupted supply lines and resulted in a shortage of grocery items in markets and caused inflation, affecting poor rural flood victims [103]. Thus, the flood impact on social, economic, physical, institutional, and natural conditions of rural communities can result in both positive and negative effect on the flow of people, information, finances, goods and services, and as a result on their vulnerability. Overall, flood vulnerability is seen as the outcome of conditions already ingrained in rural society, as well as the conditions created by the flood event (during and after) in the form of dynamics of rural-urban linkages.

Cutter [24] and Turner et al.'s [27] framework highlighted complexities, interactions, and linkages of the social-biophysical and coupled human-environmental system of place respectively. However, linkages of spatial unit i.e., rural and urban, were neglected, which this framework has highlighted. Similarly, the MOVE framework [4] did not mention the geographical conditions in terms of interdependencies between rural and urban areas. Hence, the proposed framework introduces spatial pattern of settlement-city size and proximity—as a separate factor and an important geographical feature in this study. The framework emphasized that city size and proximity are imperative in the discourse of flood vulnerability of rural areas and its relation to linkages (see Figures 4 and 5). Rural-urban linkages are highly influenced by these two factors. Theoretical concepts, like model of agriculture land use, central place theory, core-periphery model, and virtuous circle model highlighted the importance of either city size or proximity or both for linkages and rural development. Both city size and proximity can significantly influence socioeconomic and infrastructure conditions as well as institutional coverage in the surrounding rural area. In this way, rural vulnerability to floods can be influenced based on city size and proximity to the city. Moreover, these two factors can be baseline parameters in the investigation of flood vulnerability since they influence all other social, economic, institutional, and infrastructural factors, as well as rural-urban linkages. Thus, the framework emphasized the need for spatial and development planning aspects as crucial in building capacities to deal with hazards and climate change impacts (as indicated by [148,149]) in order to reduce vulnerability.

Overall, the proposed approach presented a unified framework for the assessment of rural vulnerability to floods. It identifies rural areas as not secluded units, rather interlinked with cities through different flows which were neglected by previous frameworks and studies. In this sense, the framework provided insights that rural linkage with the city can also be a driving force-in addition to other factors-of variation in rural vulnerability. Using this framework, the investigation and information on how linkages can behave in the case of a flood event, different interacting factors that are shaping linkages and their importance for the vulnerability of rural communities can bring better solutions, recommendations, and a more targeted approach to rural development and vulnerability reduction. For example, developing appropriate plans and strategies for managing these linkages in a flood situation can provide avenues for adaptation and reduce disaster risk. Thus, the framework calls for not only to focus on rural areas that are prone to hazard, disaster, or climate change impacts for intervention, but also on cities on which these rural areas depend. In addition, it can also be a feedback to the proposed framework for its applicability and further development.

\section{Conclusions}

This study presented a consolidated framework for the vulnerability assessment of rural communities by indicating that rural-urban linkages are crucial in influencing flood vulnerability. To 
do so, this paper presented a thorough review of the concept of vulnerability, its components, and conceptual frameworks, as well as the examination of terms "rural" and "urban", interaction theories, and a general understanding of rural-urban linkages. Theories and conceptual frameworks facilitated to identify factors that drive variation in rural-urban linkages and flood vulnerability. The review suggested that rural-urban linkages can be essential in influencing vulnerability of flood-prone rural communities which have not been given attention in previous conceptual frameworks. Thus, rural vulnerability to floods should not be studied in isolation, rather its relationship with urban areas is important to consider. It should not only be defined by the internal characteristics of its residents but also by considering the changing rural-urban interactions. Thus, rural-urban linkages may also provide an opportunity to reduce vulnerability of rural communities. The framework highlights to understand the multi-dimensional, differential, and dynamic nature of vulnerability and rural-urban linkages, the interaction between them, as well as the driving forces that shape the overall flood vulnerability of rural communities. Further, the role of city size and proximity is identified as an important research gap which is widely neglected in the discourse of flood vulnerability and could be imperative for improved understanding of rural vulnerability.

The framework is useful for application at the local level in developing countries. It provides multiple and broad aspects for investigation and hence can be applied in any flood-affected rural area by using their context-specific information. For example, socioeconomic, physical, institutional factors differ spatially and temporally and so are the flows. Moreover, the framework is not limited to flooding (even though the discussion revolves around flood hazards) and can be a vade mecum for other hazards considering their character and scope of impacts. For example, droughts or extreme temperatures may not affect physical infrastructure in the same way as flooding and thus linkages as well as resulting vulnerability. In this context, the framework can guide factors and the nature of influence on linkages to examine vulnerability for other hazards and propose vulnerability and risk reduction measures accordingly. Furthermore, the effectiveness of the proposed framework can be evaluated and validated through empirical investigations.

The framework is flexible and allows both qualitative and quantitative assessment of overall vulnerability based on the dynamics of rural-urban linkages. It gives freedom to develop area and hazard specific indicators and looks at overall vulnerability from the holistic and integrated perspective. Moreover, various methodological and analytical frameworks can be developed depending on different disciplines. The proposed framework has its limitations, it only considers rural areas as flood-prone and vulnerable and does not underscore how changing linkages and resulting vulnerability can indirectly affect urban areas/cities and vice versa. Moreover, urban-rural interrelationships and their related issues may vary across various regions of the world.

The paper endorses that rural-urban linkages must be incorporated into vulnerability assessments of rural communities. The proposed framework can support disaster risk reduction and climate change adaptation of rural communities by highlighting the role of cities on which rural population depends. Considering this, in addition to rural areas, necessary measures can be developed to enhance the capacities of cities so that they can support rural areas. In this context, better information delivery mechanisms, short- and long-term employment opportunities in cities, controlling price inflation, the smooth and continuous supply of goods and services, intelligent investment decisions in the reconstruction and rehabilitation phase will be the relevant areas for policymaking to strengthen linkages, curtail vulnerability, and reduce disaster risk.

Finally, the framework can be a useful tool in increasing awareness among disaster managers, regional planners, and policymakers at the local and regional levels regarding the complex and dynamic nature of vulnerability. It also calls to bring professionals from different fields-especially from climate change and disaster risk as well as regional and rural development planning communities-to coordinate and work together to gain an accurate understanding of rural-urban linkages and associated factors that determine flood vulnerability. It helps to prioritize the potential areas of intervention and delineate proper plans to support rural-urban linkages and reduce flood vulnerability as indicated 
earlier. The proposed framework contributes to recognize priority 1 of SFDRR, SDGs (goal 11 and 13), and a new urban agenda through enhanced understanding of vulnerability by suggesting the importance of linkages and facilitating the link between spatial planning and vulnerability discourse.

Author Contributions: Conceptualization: A.J., J.B., D.F., and I.A.R.-original draft preparation, A.J.; writing-review and editing, A.J., J.B., D.F., and I.A.R.; supervision, J.B.; funding acquisition A.J. All authors have read and agreed to the published version of the manuscript.

Funding: "This research was funded by Higher Education Commission (HEC), Pakistan (SAP-50020940) and German Academic Exchange Service (DAAD) (PIN = 91549672)" and "The APC was funded by University of Stuttgart".

Acknowledgments: This research work is a part of the Ph.D. process of the main (corresponding) author, at the Institute of Spatial and Regional Planning (IREUS), University of Stuttgart, Germany, under the supervision of the second author.

Conflicts of Interest: The authors declare no conflict of interest.

\section{References}

1. Jongman, B.; Winsemius, H.C.; Fraser, S.A.; Muis, S.; Ward, P.J. Assessment and Adaptation to Climate Change Related Flood Risks. In Oxford Research Encyclopedia of Natural Hazard Science; Oxford University Press: Oxford, UK, 2018; pp. 1-29. [CrossRef]

2. Jonkman, S.N. Global Perspectives on Loss of Human Life Caused by Floods. Nat. Hazards 2005, 34, 151-175. [CrossRef]

3. Intergovernmental Panel on Climate Change IPCC. Summary for Policy Makers. In Climate Change 2014: Impacts, Adaptation and Vulnerability; Field, C.B., Barros, V.R., Dokken, D.J., Mach, K.J., Mastrandrea, M.D., Bilir, T.E., Chatterjee, M., Ebi, K.L., Estrada, Y.O., Genova, R.C., et al., Eds.; Cambridge University Press: New York, NY, USA, 2014; pp. 1-34. ISBN 978-1-107-64165-5.

4. Birkmann, J.; Cardona, O.D.; Carreño, M.L.; Barbat, A.H.; Pelling, M.; Schneiderbauer, S.; Kienberger, S.; Keiler, M.; Alexander, D.; Zeil, P.; et al. Framing vulnerability, risk and societal responses: The MOVE framework. Nat. Hazards 2013, 67, 193-211. [CrossRef]

5. Jamshed, A.; Rana, I.A.; Birkmann, J.; Nadeem, O. Changes in Vulnerability and Response Capacities of Rural Communities after Extreme Events: Case of Major Floods of 2010 and 2014 in Pakistan. J. Extrem. Events 2017, 4, 1750013. [CrossRef]

6. Armah, F.A.; Yawson, D.O.; Yengoh, G.T.; Odoi, J.O.; Afrifa, E.K.A. Impact of Floods on Livelihoods and Vulnerability of Natural Resource Dependent Communities in Northern Ghana. Water 2010, 2, 120-139. [CrossRef]

7. Shah, K.U.; Dulal, H.B.; Johnson, C.; Baptiste, A. Understanding livelihood vulnerability to climate change: Applying the livelihood vulnerability index in Trinidad and Tobago. Geoforum 2013, 47, 125-137. [CrossRef]

8. Phung, D.; Rutherford, S.; Dwirahmadi, F.; Chu, C.; Do, C.M.; Nguyen, T.; Duong, N.C. The spatial distribution of vulnerability to the health impacts of flooding in the Mekong Delta, Vietnam. Int. J. Biometeorol. 2016, 60, 857-865. [CrossRef] [PubMed]

9. Rana, I.A.; Routray, J.K. Multidimensional Model for Vulnerability Assessment of Urban Flooding: An Empirical Study in Pakistan. Int. J. Disaster Risk Sci. 2018, 9, 359-375. [CrossRef]

10. Bhattacharjee, K.; Behera, B. Determinants of household vulnerability and adaptation to floods: Empirical evidence from the Indian State of West Bengal. Int. J. Disaster Risk Reduct. 2018, 31, 758-769. [CrossRef]

11. Shah, A.A.; Ye, J.; Abid, M.; Khan, J.; Amir, S.M. Flood hazards: Household vulnerability and resilience in disaster-prone districts of Khyber Pakhtunkhwa province, Pakistan. Nat. Hazards 2018, 93, 147-165. [CrossRef]

12. Brouwer, R.; Akter, S.; Brander, L.; Haque, E. Socioeconomic vulnerability and adaptation to environmental risk: A case study of climate change and flooding in Bangladesh. Risk Anal. 2007, 27, 313-326. [CrossRef]

13. Tanoue, M.; Hirabayashi, Y.; Ikeuchi, H. Global-scale river flood vulnerability in the last 50 years. Sci. Rep. 2016, 6, 36021. [CrossRef] [PubMed]

14. Feldmeyer, D.; Birkmann, J.; Welle, T. Development of Human Vulnerability 2012-2017. J. Extrem. Events 2017, 4, 1850005. [CrossRef] 
15. Cross, J.A. Megacities and small towns: Different perspectives on hazard vulnerability. Environ. Hazards 2001, 3, 63-80. [CrossRef]

16. Turpie, J.; Visser, M. The Impact of Climate Change on South Africa's Rural Areas. In Technical Report: Submission for the 2013/14 Division of Revenue; Financial and Fiscal Commission, Ed.; Financial and Fiscal Commission: Midrand, South Africa, 2012; pp. 100-162.

17. Paavola, J. Livelihoods, vulnerability and adaptation to climate change in Morogoro, Tanzania. Environ. Sci. Policy 2008, 11, 642-654. [CrossRef]

18. Dasgupta, P.; Morton, J.F.; Dodman, D.; Karapinar, B.; Meza, F.; Ferre, M.G.; Sarr, A.T.; Vincent, K.E. Rural Areas. In Climate Change 2014: Impacts, Adaptation, and Vulnerability. Part A, Global and Sectoral Aspects; Agard, J., Schipper, E.L.F., Birkmann, J., Campos, M., Dubeux, C., Eds.; Cambridge University Press: New York, NY, USA, 2014; pp. 613-657. ISBN 978-1-107-02506-6.

19. Steinberg, F. Rural-Urban Linkages: An Urban Perspective. Working Paper No. 128. 2014. Available online: http://rimisp.org/wp-content/files_mf/1422298948R_ULinkages_Urbanperspective_Final_edited.pdf (accessed on 20 August 2016).

20. United Nations Department of Economic and Social Affairs UN-DESA. World Urbanization Prospects: The 2018 Revision. Available online: https://population.un.org/wup/Download/ (accessed on 10 October 2019).

21. Srivastava, N.; Shaw, R. Enhancing City Resilience through Urban-Rural Linkages. In Urban Disasters and Resilience in Asia; Shaw, R., Rahman, A.-U., Surjan, A., Parvin, G., Eds.; Butterworth-Heinemann: Amsterdam, The Netherlands, 2016; pp. 113-122. ISBN 9780128021699.

22. Gebre, T.; Gebremedhin, B. The mutual benefits of promoting rural-urban interdependence through linked ecosystem services. Glob. Ecol. Conserv. 2019, 20, e00707. [CrossRef]

23. Jamshed, A.; Birkmann, J.; McMillan, J.M.; Rana, I.A.; Hannes, L. The Impact of Extreme Floods on Rural Communities: Evidence from Pakistan. In Climate Change, Hazards and Adaptation Options: Handling the Impacts of a Changing Climate, 1st ed.; Leal, W.F., Nagy, G., Borga, M., Chavez, D., Magnuszewski, A., Eds.; Springer: Cham, Switzerland, 2020; pp. 585-613. ISBN 9783030374242.

24. Cutter, S.L. Vulnerability to environmental hazards. Prog. Hum. Geogr. 1996, 20, 529-539. [CrossRef]

25. Department for International Development DFID. Sustainable Livelihoods Guidance Sheet. 1999. Available online: https://worldfish.org/GCI/gci_assets_moz/Livelihood\%20Approach\%20-\%20DFID.pdf (accessed on 5 May 2015).

26. Cardona, O.D.; Barbat, A.H. El Riesgo Sísmico y su Prevención; Cuaderno Técnico 5: Madrid, Spain, 2000.

27. Turner, B.L.; Kasperson, R.E.; Matson, P.A.; McCarthy, J.J.; Corell, R.W.; Christensen, L.; Eckley, N.; Kasperson, J.X.; Luers, A.; Martello, M.L.; et al. A framework for vulnerability analysis in sustainability science. Proc. Natl. Acad. Sci. USA. 2003, 100, 8074-8079. [CrossRef]

28. Wisner, B.; Blaikie, P.; Cannon, T.; Davis, I. At Risk: Natural Hazards, People's Vulnerability and Disasters, 2nd ed.; Routledge: New York, NY, USA, 2004; ISBN 978-1-134-52861-5.

29. Bohle, H.-G. Vulnerability and criticality: Perspectives from social geography. Int. Hum. Dimens. Programme Glob. Environ. Chang. 2001, 2, 3-5.

30. Birkmann, J. Measuring vulnerability to promote disaster resilient societies: Conceptual framework and definitions. In Measuring Vulnerability to Natural Hazards: Towards Disaster Resilient Societies; Birkmann, J., Ed.; United Nations University Press: Tokyo, Japan, 2006; pp. 9-54. ISBN 978-81-7993-122-6.

31. Füssel, H.-M.; Klein, R.J.T. Climate Change Vulnerability Assessments: An Evolution of Conceptual Thinking. Clim. Chang. 2006, 75, 301-329. [CrossRef]

32. Romanescu, G.; Hapciuc, O.E.; Minea, I.; Iosub, M. Flood vulnerability assessment in the mountain-plateau transition zone: A case study of Marginea village (Romania). J. Flood Risk Manag. 2018, 11, S502-S513. [CrossRef]

33. Munyai, R.B.; Musyoki, A.; Nethengwe, N.S. An assessment of flood vulnerability and adaptation: A case study of Hamutsha-Muungamunwe village, Makhado municipality. Jamba 2019, 11, 692. [CrossRef] [PubMed]

34. Hahn, M.B.; Riederer, A.M.; Foster, S.O. The Livelihood Vulnerability Index: A pragmatic approach to assessing risks from climate variability and change-A case study in Mozambique. Glob. Environ. Chang. 2009, 19, 74-88. [CrossRef] 
35. Sarker, M.; Wu, M.; Alam, G.; Shouse, R. Livelihood Vulnerability of Riverine-Island Dwellers in the Face of Natural Disasters in Bangladesh. Sustainability 2019, 11, 1623. [CrossRef]

36. Cardona, O.D.; van Aalst, M.K.; Birkmann, J.; Fordham, M.; McGregor, G.; Perez, R.; Pulwarty, R.S.; Schipper, E.L.F.; Sinh, B.T. Chapter 2: Determinants of risk: Exposure and vulnerability. In Managing the Risks of Extreme Events and Disasters to Advance Climate Change Adaption: Special Report of the Intergovernmental Panel on Climate Change; Field, C.B., Barros, V., Stocker, T.F., Dahe, Q., Dokken, D.J., Ebi, K.L., Mastrandrea, M.D., Mach, K.J., Plattner, G.-K., Allen, S.K., et al., Eds.; Cambridge University Press: Cambridge, UK, 2012; pp. 67-96. ISBN 978-1-107-02506-6.

37. O’Brien, K.; Pelling, M.; Patwardha, A.; Hallegatte, S.; Maskrey, A.; Oki, T.; Oswald-Spring, Ú; Wilbanks, T.; Yanda, P.Z. Toward a Sustainable and Resilient Future. In Managing the Risks of Extreme Events and Disasters to Advance Climate Change Adaptation: Special Report of the Intergovernmental Panel on Climate Change; Field, C.B., Barros, V., Stocker, T.F., Dahe, Q., Dokken, D.J., Ebi, K.L., Mastrandrea, M.D., Mach, K.J., Plattner, G.-K., Allen, S.K., et al., Eds.; Cambridge University Press: Cambridge, UK, 2012; pp. 437-486. ISBN 978-1-107-02506-6.

38. Srivastava, N.; Shaw, R. Occupational resilience to floods across the urban-rural domain in Greater Ahmedabad, India. Int. J. Disaster Risk Reduct. 2015, 12, 81-92. [CrossRef]

39. Douglass, M. A regional network strategy for reciprocal rural-urban linkages: An agenda for policy research with reference to Indonesia. Third World Plan. Rev. 1998, 20, 1. [CrossRef]

40. Bah, M.; Cissè, S.; Diyamett, B.; Diallo, G.; Lerise, F.; Okali, D.; Okpara, E.; Olawoye, J.; Tacoli, C. Changing rural-urban linkages in Mali, Nigeria and Tanzania. Environ. Urban. 2003, 15, 13-24. [CrossRef]

41. Lynch, K. Rural-urban Interaction in the Developing World; Routledge: London, UK, 2005; ISBN 0415258715.

42. Tacoli, C. Poverty, Inequality and the Underestimation of Rural-urban Linkages. Development 2007, 50, 90-95. [CrossRef]

43. Das, I.; Dutta, M.K.; Borbora, S. Rural-urban Linkages for Development of Rural Economy in Assam: A Social Accounting Matrix Approach. Int. J. Rural 2013, 9, 183-208. [CrossRef]

44. Berdegué, J.A.; Carriazo, F.; Jara, B.; Modrego, F.; Soloaga, I. Cities, Territories, and Inclusive Growth: Unraveling Urban-Rural Linkages in Chile, Colombia, and Mexico. World Dev. 2015, 73, 56-71. [CrossRef]

45. Mayer, H.; Habersetzer, A.; Meili, R. Rural-Urban Linkages and Sustainable Regional Development: The Role of Entrepreneurs in Linking Peripheries and Centers. Sustainability 2016, 8, 745. [CrossRef]

46. Srivastava, N.; Shaw, R. Employment: Interrelationship of Disaster and Employment from the Perspective of Urban-Rural Linkages in India. In Environment Disaster Linkages, 1st ed.; Shaw, R., Tran, P., Eds.; Emerald: Bingley, UK, 2012; pp. 145-164. ISBN 0857248669.

47. UNDRR. Sendai Framework for Disaster Risk Reduction 2015-2030. 2015. Available online: https: //www.unisdr.org/files/43291_sendaiframeworkfordrren.pdf (accessed on 15 May 2016).

48. United Nations. Sustainable Development Goals Report 2018; United Nations Publications: New York, NY, USA, 2018; ISBN 978-92-1-101390-0.

49. UNHABITAT. Implementing the New Urban Agenda by Strengthening Urban-rural Linkages. Leave No One And No Space Behind HS/035/17E. 2017. Available online: http://www.uncrd.or.jp/content/ documents/7015Urban\%20Rural\%20Linkages\%20for\%20implementing\%20the\%20New\%20Urban\% 20Agenda_08112017_spreads.pdf (accessed on 7 July 2019).

50. UNHABITAT. HABITAT III the New Urban Agenda: 2016. Available online: https://www2.habitat3.org/ bitcache/97ced11dcecef85d41f74043195e5472836f6291?vid=588897\&disposition=inline\&op=view (accessed on 30 October 2016).

51. Rana, I.A.; Routray, J.K.; Younas, Z.I. Spatiotemporal dynamics of development inequalities in Lahore City Region, Pakistan. Cities 2020, 96, 102418. [CrossRef]

52. United Nations Department of Economic and Social Affairs UN-DESA. United Nations Demographic Yearbook 2017, 68th ed.; United Nations Publications: New York, NY, USA, 2018; ISBN 9789211483055.

53. Tacoli, C. Rural-urban interactions: A guide to the literature. Environ. Urban. 1998, 10, 147-166. [CrossRef]

54. Lerner, A.M.; Eakin, H. An obsolete dichotomy? Rethinking the rural-urban interface in terms of food security and production in the global south. Geogr. J. 2011, 177, 311-320. [CrossRef] [PubMed]

55. von Thunen, J.H. Von Thunen's Isolated State. An English Edition of 'Dcr Isolierte Staat' translated by Bassett, I. G. in 1966. N. Z. Geogr. 1826, 23, 91-92. [CrossRef] 
56. Christaller, W. Central Places in Southern Germany; Baskin, C.W., Ed.; Prentice-Hall: Upper Saddle River, NJ, USA, 1933.

57. Perroux, F. Note sur la notion de pole de croissance? Écon. Appl. 1955, 8, 307-320.

58. Friedmann, J.R.P. Regional Development Policy. A Case Study of Venezuela, 2nd ed.; M.I.T. Press: Cambridge, UK, 1966; ISBN 9780262060134.

59. Evans, H.E. A virtuous circle model of rural-urban development: Evidence from a Kenyan small town and its Hinterland. J. Dev. Stud. 1992, 28, 640-667. [CrossRef]

60. Rees, W.E. Ecological footprints and appropriated carrying capacity: What urban economics leaves out. Environ. Urban. 1992, 4, 121-130. [CrossRef]

61. Wackernagel, M.; Rees, W. Our Ecological Footprint. Reducing Human Impact on Earth; New Society Publishers: Philadelphia, PA, USA, 1996; ISBN 0-86571-312-X.

62. Tacoli, C.; Mabala, R. Exploring mobility and migration in the context of rural-Urban linkages: Why gender and generation matter. Environ. Urban. 2010, 22, 389-395. [CrossRef]

63. Tacoli, C. The links between urban and rural development. Environ. Urban. 2003, 15, 3-12. [CrossRef]

64. Luna, F. Vulnerability. In Encyclopedia of the Anthropocene; Dellasala, D.A., Goldstein, M.I., Eds.; Elsevier: Amsterdam, The Netherlands, 2018; pp. 127-135. ISBN 9780128135761.

65. Birkmann, J. Measuring vulnerability to promote disaster-resilient societies and to enhance adaptation: Conceptual frameworks and definitions. In Measuring Vulnerability to Natural Hazards: Towards Disaster Resilient Societies, 2nd ed.; Birkmann, J., Ed.; United Nations University Press: Tokyo, Japan, 2013; pp. 9-79. ISBN 9789280871715.

66. Adger, W.N. Vulnerability. Glob. Environ. Chang. 2006, 16, 268-281. [CrossRef]

67. Mitchell, J.K. Hazard Research. In Geography in America; Willmott, C.J., Ed.; Merrill: Colombus, OH, USA, 1989; pp. 410-424. ISBN 978-0-675-20648-8.

68. Cutter, S.L. Living with Risk. The Geography of Technological Hazards; Edward Arnold Publication: London, UK, 1993; ISBN 0340529873.

69. Blaikie, P.; Cannon, T.; Davis, I.; Wisner, B. At Risk: Natural Hazards, People's Vulnerability and Disasters; Routledge: London, UK, 1994; ISBN 978-1-134-52860-8.

70. Adger, N.W. Social Vulnerability to Climate Change and Extremes in Coastal Vietnam. World Dev. 1999, 27, 249-269. [CrossRef]

71. Intergovernmental Panel on Climate Change IPCC. Climate Change 2007: The Physical Science Basis: Contribution of Working Group I to the Fourth Assessment Report of the Intergovernmental Panel on Climate Change; Cambridge University Press: Cambridge, NY, USA, 2007; ISBN 978-0-521-88009-1.

72. United Nations Office of Disaster Risk Reduction UNDRR. UNDRR Terminology on Disaster Risk Reduction. 2009. Available online: https://www.unisdr.org/files/7817_UNISDRTerminologyEnglish.pdf (accessed on 19 March 2018).

73. Birkmann, J.; Fernando, N. Measuring revealed and emergent vulnerabilities of coastal communities to tsunami in Sri Lanka. Disasters 2008, 32, 82-105. [CrossRef] [PubMed]

74. Cannon, T.; Twigg, J.; Rowell, J. Social Vulnerability, Sustainable Livelihoods and Disasters. 2003. Available online: http://www.radixonline.org/resources/dfid-vuln\&live-rep.pdf (accessed on 20 September 2019).

75. Costa, L.; Kropp, J.P. Linking components of vulnerability in theoretic frameworks and case studies. Sustain. Sci. 2013, 8, 1-9. [CrossRef]

76. Intergovernmental Panel on Climate Change IPCC. Annex-II: Glossary of Terms. In Climate Change 2014: Impacts, Adaptation, and Vulnerability. Part A, Global and Sectoral Aspects; Agard, J., Schipper, E.L.F., Birkmann, J., Campos, M., Dubeux, C., Eds.; Cambridge University Press: New York, NY, USA, 2014; ISBN 978-1-107-02506-6.

77. Engle, N.L. Adaptive capacity and its assessment. Glob. Environ. Chang. 2011, 21, 647-656. [CrossRef]

78. United Nations Office of Disaster Risk Reduction UNDRR. Report of the Open-ended Intergovernmental Expert Working Group on Indicators and Terminology Relating to Disaster Risk Reduction A/71/644. 2017. Available online: https://www.preventionweb.net/files/50683_oiewgreportenglish.pdf (accessed on 19 March 2018).

79. Smit, B.; Wandel, J. Adaptation, adaptive capacity and vulnerability. Glob. Environ. Chang. 2006, 16, $282-292$. [CrossRef] 
80. Gallopín, G.C. Linkages between vulnerability, resilience, and adaptive capacity. Glob. Environ. Chang. 2006, 16, 293-303. [CrossRef]

81. Birkmann, J.; Buckle, P.; Jaeger, J.; Pelling, M.; Setiadi, N.; Garschagen, M.; Fernando, N.; Kropp, J. Extreme events and disasters: A window of opportunity for change? Analysis of organizational, institutional and political changes, formal and informal responses after mega-disasters. Nat. Hazards 2010, 55, 637-655. [CrossRef]

82. Jamshed, A.; Rana, I.A.; Mirza, U.M.; Birkmann, J. Assessing relationship between vulnerability and capacity: An empirical study on rural flooding in Pakistan. Int. J. Disaster Risk Reduct. 2019, 36, 101109. [CrossRef]

83. Brooks, N.; Vulnerability, Risk and Adaptation. A Conceptual Framework; Working Paper No. 38. 2003. Available online: https://www.researchgate.net/profile/Nick_Brooks2/publication/200032746_Vulnerability_ Risk_and_Adaptation_A_Conceptual_Framework/links/0fcfd50ac169e15865000000.pdf (accessed on 26 November 2019).

84. Nazari, S.; Rad, G.P.; Sedighi, H.; Azadi, H. Vulnerability of wheat farmers: Toward a conceptual framework. Ecol. Indic. 2015, 52, 517-532. [CrossRef]

85. Füssel, H.-M. Vulnerability in Climate Change Research: A Comprehensive Conceptual Framework; Breslauer Symposium. 2005. Available online: https:/escholarship.org/uc/item/8993z6nm\#author (accessed on 26 November 2019).

86. Black, R.; Arnell, N.W.; Adger, W.N.; Thomas, D.; Geddes, A. Migration, immobility and displacement outcomes following extreme events. Environ. Sci. Policy 2013, 27, S32-S43. [CrossRef]

87. Warner, K.; Afifi, T.; Kälin, W.; Leckie, S.; Ferris, E.G.; Martin, S.F.; Wrathall, D. Changing Climate, Moving People. Framing Migration, Displacement and Planned Relocation; UNU-EHS: Bonn, Germany, 2013; ISBN 3944535022.

88. Guadagno, L. Human Mobility in the Sendai Framework for Disaster Risk Reduction. Int. J. Disaster Risk Sci. 2016, 7, 30-40. [CrossRef]

89. Mutton, D.; Haque, C.E. Human Vulnerability, Dislocation and Resettlement: Adaptation Processes of River-bank Erosion-induced Displacees in Bangladesh. Disasters 2004, 28, 41-62. [CrossRef] [PubMed]

90. Guzder, D. Pakistan's IDP Relief Camps: A Tenuous Sanctuary. Available online: https://pulitzercenter.org/ reporting/pakistans-idp-relief-camps-tenuous-sanctuary (accessed on 30 October 2019).

91. The Guardian. Kerala: More than 1m People Flee to Relief Camps to Escape Floods. Available online: https://www.theguardian.com/world/2018/aug/21/kerala-india-more-than-1m-people-flee-to-reliefcamps-to-escape-floods (accessed on 10 October 2019).

92. Ferdous, M.R.; Wesselink, A.; Brandimarte, L.; Slager, K.; Zwarteveen, M.; Di Baldassarre, G. The Costs of Living with Floods in the Jamuna Floodplain in Bangladesh. Water 2019, 11, 1238. [CrossRef]

93. McLeman, R.; Smit, B. Migration as an Adaptation to Climate Change. Clim. Chang. 2006, 76, 31-53. [CrossRef]

94. Tacoli, C. Crisis or adaptation? Migration and climate change in a context of high mobility. Environ. Urban. 2009, 21, 513-525. [CrossRef]

95. Suckall, N.; Fraser, E.; Forster, P.; Mkwambisi, D. Using a migration systems approach to understand the link between climate change and urbanisation in Malawi. Appl. Geogr. 2015, 63, 244-252. [CrossRef]

96. Suckall, N.; Fraser, E.; Forster, P. Reduced migration under climate change: Evidence from Malawi using an aspirations and capabilities framework. Clim. Dev. 2017, 9, 298-312. [CrossRef]

97. Engeler, E. Mass Communications Programme Talks and Listens to Pakistan's Flood Victims. In Migration: Pakistan Floods: After the Deluge $\mathcal{E}$ The Future of Migration? Chauzy, J.P., Ed.; International Organization for Migration: Geneva, Switzerland, 2010; pp. 8-10. ISBN 1813-2855.

98. Abid, M.; Schilling, J.; Scheffran, J.; Zulfiqar, F. Climate change vulnerability, adaptation and risk perceptions at farm level in Punjab, Pakistan. Sci. Total Environ. 2016, 547, 447-460. [CrossRef]

99. Le De, L.; Gaillard, J.C.; Friesen, W.; Smith, F.M. Remittances in the face of disasters: A case study of rural Samoa. Environ. Dev. Sustain. 2015, 17, 653-672. [CrossRef]

100. Pairama, J.; Le Dé, L. Remittances for Disaster Risk Management: Perspectives from Pacific Island Migrants Living in New Zealand. Int. J. Disaster Risk Sci. 2018, 9, 331-343. [CrossRef]

101. Rakib, M.A.; Islam, S.; Nikolaos, I.; Bodrud-Doza, M.; Bhuiyan, M.A.H. Flood vulnerability, local perception and gender role judgment using multivariate analysis: A problem-based "participatory action to Future Skill Management" to cope with flood impacts. Weather Clim. Extrem. 2017, 18, 29-43. [CrossRef] 
102. Abid, M.; Ngaruiya, G.; Scheffran, J.; Zulfiqar, F. The Role of Social Networks in Agricultural Adaptation to Climate Change: Implications for Sustainable Agriculture in Pakistan. Climate 2017, 5, 85. [CrossRef]

103. Zyck, S.A.; Mosel, I.; Khan, H.D.; Shabbir, S. Markets in Crises: The 2010 Floods in Sindh, Pakistan. Working Paper. 2015. Available online: https://www.odi.org/publications/10089-markets-crises-2010-floods-sindhpakistan (accessed on 17 September 2016).

104. Arai, T. Rebuilding Pakistan in the Aftermath of the Floods: Disaster Relief as Conflict Prevention. J. Peacebuild. Dev. 2012, 7, 51-65. [CrossRef]

105. Maertens, A.; Barrett, C.B. Measuring Social Networks' Effects on Agricultural Technology Adoption. Am. J. Agric. Econ. 2013, 95, 353-359. [CrossRef]

106. Mitra, A.; Murayama, M. Rural to Urban Migration: A District-Level Analysis for India. Int. J. Migr. Health Soc. Care 2009, 5, 35-52. [CrossRef]

107. Liu, Y.; Li, Z.; Breitung, W. The social networks of new-generation migrants in China's urbanized villages: A case study of Guangzhou. Habitat Int. 2012, 36, 192-200. [CrossRef]

108. Okten, C.; Osili, U.O. Social Networks and Credit Access in Indonesia. World Dev. 2004, 32, $1225-1246$. [CrossRef]

109. Rana, I.A.; Routray, J.K. Actual vis-à-vis perceived risk of flood prone urban communities in Pakistan. Int. J. Disaster Risk Reduct. 2016, 19, 366-378. [CrossRef]

110. Lianxiao; Morimoto, T. Spatial Analysis of Social Vulnerability to Floods Based on the MOVE Framework and Information Entropy Method: Case Study of Katsushika Ward, Tokyo. Sustainability 2019, 11, 529. [CrossRef]

111. Mustafa, D. Structural Causes of Vulnerability to Flood Hazard in Pakistan*. Econ. Geogr. 1998, 74, $289-305$. [CrossRef]

112. Sorg, L.; Medina, N.; Feldmeyer, D.; Sanchez, A.; Vojinovic, Z.; Birkmann, J.; Marchese, A. Capturing the multifaceted phenomena of socioeconomic vulnerability. Nat. Hazards 2018, 11, 308. [CrossRef]

113. Paul, S.K.; Routray, J.K. Flood proneness and coping strategies: The experiences of two villages in Bangladesh. Disasters 2010, 34, 489-508. [CrossRef] [PubMed]

114. Scheuer, S.; Haase, D.; Meyer, V. Exploring multicriteria flood vulnerability by integrating economic, social and ecological dimensions of flood risk and coping capacity: From a starting point view towards an end point view of vulnerability. Nat. Hazards 2011, 58, 731-751. [CrossRef]

115. Boon, H.J. Disaster resilience in a flood-impacted rural Australian town. Nat. Hazards 2014, 71, $683-701$. [CrossRef]

116. Shah, A.A.; Ye, J.; Abid, M.; Ullah, R. Determinants of flood risk mitigation strategies at household level: A case of Khyber Pakhtunkhwa (KP) province, Pakistan. Nat. Hazards 2017, 88, 415-430. [CrossRef]

117. Few, R. Flooding, vulnerability and coping strategies: Local responses to a global threat. Prog. Dev. Stud. 2003, 3, 43-58. [CrossRef]

118. Motsholapheko, M.R.; Kgathi, D.L.; Vanderpost, C. Rural livelihood diversification: A household adaptive strategy against flood variability in the Okavango Delta, Botswana. Agrekon 2012, 51, 41-62. [CrossRef]

119. Younus, M.A.F. An assessment of vulnerability and adaptation to cyclones through impact assessment guidelines: A bottom-up case study from Bangladesh coast. Nat. Hazards 2017, 89, 1437-1459. [CrossRef]

120. Sam, A.S.; Kumar, R.; Kächele, H.; Müller, K. Vulnerabilities to flood hazards among rural households in India. Nat. Hazards 2017, 88, 1133-1153. [CrossRef]

121. Andrade, M.M.N.d.; Szlafsztein, C.F. Vulnerability assessment including tangible and intangible components in the index composition: An Amazon case study of flooding and flash flooding. Sci. Total Environ. 2018, 630, 903-912. [CrossRef]

122. von Braun, J. Rural-urban Linkages for Growth, Employment, and Poverty Reduction. In Proceedings of the Fifth International Conference on the Ethiopian Economy, Addis Ababa, Ethiopia, 7-9 June 2007; Available online: https://pdfs.semanticscholar.org/c194/3092c3d0c0600061f96185fddb9599a6885d.pdf (accessed on 9 October 2019).

123. Satterthwaite, D.; Tacoli, C. The role of small and intermediate urban centres in regional and rural development: Assumptions and evidence. In The Earthscan Reader in Rural-Urban Linkages; Tacoli, C., Ed.; Earthscan: London, UK, 2006; pp. 155-183. ISBN 1844073165.

124. Cook, P. Infrastructure, rural electrification and development. Energy Sustain. Dev. 2011, 15, $304-313$. [CrossRef] 
125. Akkoyunlu, S. The Potential of Rural-Urban Linkages for Sustainable Development and Trade. Int. J. Sustain. Dev. World Policy 2015, 4, 20-40. [CrossRef]

126. Abbas, B.H.; Routray, J.K. Vulnerability to flood-induced public health risks in Sudan. Disaster Prev. Manag. 2014, 23, 395-419. [CrossRef]

127. Abid, M.; Scheffran, J.; Schneider, U.A.; Ashfaq, M. Farmers' perceptions of and adaptation strategies to climate change and their determinants: The case of Punjab province, Pakistan. Earth Syst. Dyn. 2015, 6, 225-243. [CrossRef]

128. Deichmann, U.; Shilpi, F.; Vakis, R. Urban Proximity, Agricultural Potential and Rural Non-farm Employment: Evidence from Bangladesh. World Dev. 2009, 37, 645-660. [CrossRef]

129. Abbay, A.G.; Rutten, R. Does spatial proximity to small towns matter for rural livelihoods? A propensity score matching analysis in Ethiopia. Lett. Spat. Resour. Sci. 2016, 9, 287-307. [CrossRef]

130. Hsu, W.-T. Central Place Theory and City Size Distribution. Econ. J. 2012, 122, 903-932. [CrossRef]

131. Romić, I. Functional diversity in Keihanshin Metropolitan Area. Reg. Stud. Reg. Sci. 2018, 5, $204-211$. [CrossRef]

132. Schmitt, B.; Henry, M.S. Size and growth of urban centers in French labor market areas: Consequences for rural population and employment. Reg. Sci. Urban Econ. 2000, 30, 1-21. [CrossRef]

133. Henry, M.S.; Schmitt, B.; Kristensen, K.; Barkley, D.L.; Bao, S. Extending Carlino-Mills Models to Examine Urban Size and Growth Impacts on Proximate Rural Areas. Growth Chang. 1999, 30, 526-548. [CrossRef]

134. Ferré, C.; Ferreira, F.H.G.; Lanjouw, P. Is There a Metropolitan Bias? The relationship between poverty and city size in a selection of developing countries. World Bank Econ. Rev. 2012, 26, 351-382. [CrossRef]

135. Tacoli, C. The Earthscan Reader in Rural-Urban Linkages; Tacoli, C., Ed.; Earthscan: London, UK, 2006; ISBN 1844073165.

136. Fafchamps, M.; Shilpi, F. The spatial division of labour in Nepal. J. Dev. Stud. 2003, 39, 23-66. [CrossRef]

137. Sharma, A. Urban Proximity and Spatial Pattern of Land Use and Development in Rural India. J. Dev. Stud. 2016, 52, 1593-1611. [CrossRef]

138. Duvivier, C.; Li, S.; Renard, M.-F. Are workers close to cities paid higher nonagricultural wages in rural China? Appl. Econ. 2013, 45, 4308-4322. [CrossRef]

139. Ahmed, U.I.; Ying, L.; Bashir, M.K.; Abid, M.; Zulfiqar, F. Status and determinants of small farming households' food security and role of market access in enhancing food security in rural Pakistan. PLoS ONE 2017, 12, e0185466. [CrossRef]

140. Birkmann, J.; Welle, T.; Solecki, W.; Lwasa, S.; Garschagen, M. Boost resilience of small and mid-sized cities. Nature 2016, 537, 605-608. [CrossRef]

141. Fang, C.; Wang, Y.; Fang, J. A comprehensive assessment of urban vulnerability and its spatial differentiation in China. J. Geogr. Sci. 2016, 26, 153-170. [CrossRef]

142. Handayani, W.; Rudiarto, I.; Setyono, J.S.; Chigbu, U.E.; Sukmawati, A.M.A. Vulnerability assessment: A comparison of three different city sizes in the coastal area of Central Java, Indonesia. Adv. Clim. Chang. Res. 2017, 8, 286-296. [CrossRef]

143. Maddison, D. The Perception of and Adaptation to Climate Change in Africa. Policy Research Working Paper No. 4308. 2007. Available online: https:/openknowledge.worldbank.org/bitstream/handle/10986/ 7507/wps4308.pdf? sequence=1\&isAllowed=y (accessed on 25 August 2018).

144. Pandey, R.; Jha, S.K.; Alatalo, J.M.; Archie, K.M.; Gupta, A.K. Sustainable livelihood framework-based indicators for assessing climate change vulnerability and adaptation for Himalayan communities. Ecol. Indic. 2017, 79, 338-346. [CrossRef]

145. Gain, A.K.; Mojtahed, V.; Biscaro, C.; Balbi, S.; Giupponi, C. An integrated approach of flood risk assessment in the eastern part of Dhaka City. Nat. Hazards 2015, 79, 1499-1530. [CrossRef]

146. Penning-Rowsell, E.; Floyd, P.; Ramsbottom, D.; Surendran, S. Estimating Injury and Loss of Life in Floods: A Deterministic Framework. Nat. Hazards 2005, 36, 43-64. [CrossRef]

147. Luu, C.; von Meding, J. A Flood Risk Assessment of Quang Nam, Vietnam Using Spatial Multicriteria Decision Analysis. Water 2018, 10, 461. [CrossRef] 
148. Greiving, S.; Fleischhauer, M.; Wanczura, S. Management of natural hazards in Europe: The role of spatial planning in selected EU member states. J. Environ. Plan. Manag. 2006, 49, 739-757. [CrossRef]

149. Greiving, S.; Fleischhauer, M. National Climate Change Adaptation Strategies of European States from a Spatial Planning and Development Perspective. Eur. Plan. Stud. 2012, 20, 27-48. [CrossRef]

(C) 2020 by the authors. Licensee MDPI, Basel, Switzerland. This article is an open access article distributed under the terms and conditions of the Creative Commons Attribution (CC BY) license (http://creativecommons.org/licenses/by/4.0/). 